Article

\title{
Living Cost Gap in the European Union Member States
}

\author{
Andrius Kučas *D, Boyan Kavalov and Carlo Lavalle \\ European Commission, Joint Research Centre (JRC), 21027 Ispra, Italy; boyan.kavalov@ec.europa.eu (B.K.); \\ carlo.lavalle@ec.europa.eu (C.L.) \\ * Correspondence: andrius.kucas@ec.europa.eu; Tel.: +39-033-278-9445
}

Received: 16 September 2020; Accepted: 24 October 2020; Published: 28 October 2020

\begin{abstract}
The living cost gap refers to the differential amongst income, expenditures, and poverty lines. It is important since it addresses a number of aspects that point towards historic and continued living standards. The purpose of this study is to identify, measure, and compare the living cost gap in the Europe Union member states. Twenty-nine indicators/criteria from Eurostat and World Bank, covering the period 2008-2017, are employed. In order to rank and compare living cost gap by countries, objective functions for each criterion are defined and applied. The importance of each criterion is assessed independently. The composite living cost gap indicator for each MS is calculated using multiple criteria decision support methods. The relationship between the compound annual growth rates of this indicator and each single criterion is estimated and evaluated. The findings of the study suggest that living cost gap is higher where unemployment rates and households' expenditure on basic needs (housing, food etc.), are larger, while living cost gap is lower where households' income and expenditure on optional needs are higher. The living cost gap in the majority of countries tends to narrow/decrease, along with the increase in the household income and expenditures. Our research highlights the need to mitigate unemployment and households' low net income in order to alleviate living cost gap. The analysis and assessment of living cost gap might help identifying the most vulnerable social profiles and groups, and hence might contribute to the adequate formulation and implementation of targeted policy responses and interventions at European Union, national, and regional level.
\end{abstract}

Keywords: household; income; expenditures; multiple-criteria decision making; compound annual growth rate

\section{Introduction}

Territorial inequalities have long been studied and dealt with in the literature and in policy [1-8], but still many research questions remained unanswered and many issues unsolved [9]. Therefore, there is historical and continuous interest to analyse territorial disparities through new lenses and produce knowledge useful to understand the cost of living combining the characteristics of places and social connections [10]. By definition, the cost of living is the amount of money needed to sustain a certain standard of living by affording basic expenses. An increasing divergence in living standards and costs is being recently observed across Europe, partially because much of Europe's economic growth has been uneven, mostly occurring in larger regions $[8,11]$.

The notion "Living Cost Gap" (LCG) refers to the differential amongst income [12,13], expenditure [14,15], employment [16-18], and poverty $[19,20]$, usually aggravated by economic crises and recessions [20-23]. 
The LCG challenge is important since it addresses a number of aspects that point towards a historic and continued living standards and expected stress-related behaviour when the living cost burden occurs [20,24-27].

The most attractive places to live are generally defined by the optimum ratio between income and expenses [28,29]. Other factors such as housing conditions and life satisfaction [25], personal safety and security [26], availability of good transport infrastructure [30], education [28], attractive labour market [31], and reduced risk of poverty [20,32] might be considered as additional benefits for the households.

Due to a generally favourable combination of those factors, people tend to live in urbanised areas (cities, towns, or suburbs). Consequently, the non-urbanised (rural) areas are becoming less populated. Amongst others, this is due to the consolidation of innovation-driven and efficient production toolsets in the primary sector (agriculture, forestry and fisheries) that largely dominates the economy of rural areas. This phenomena reduces the labour demand, resulting in declining employment and retarded growth of rural income [33]. It is not very likely that growth in secondary and tertiary sectors of economy in rural areas can solve poverty problems in the foreseeable future, especially in many backward regions [34]. On the other hand, the negative impacts in large cities, such as labour crowding and elevated cost of living, may boost the appeal of smaller urban centres and rural regions [11].

It is therefore important to monitor the evolution of those factors taken altogether, i.e., territorial volatility, while urban areas expand and population increases. In such a way, one prevents attractive areas to transform into less attractive or unattractive ones due to fewer and/or poorer job offers, higher risk of poverty, and less affordable living cost. The lack of job opportunities and thus sufficient income to guarantee a minimum standard of living or even-minimum level for surviving, leads to poverty, deprivation, and ultimately boosts LCG.

The rising awareness of the negative effects from urban poverty, followed by LCG, has resulted in a rapidly increasing number of requests for new policy incentives aimed at reducing the risk of poverty and vulnerability, more affordable living cost costs, more and better opportunities for employment, and income earning $[19,35]$. In a broader context, there is growing demand for comprehensive scientific knowledge and tools to enhance environmental, economic, and social values of separate processes by managing them in accordance with the principles of integrated sustainability [36]. However, decision-makers often deal with problems that involve multiple conflicting criteria [37-40]. Closing or at least narrowing the LCG is a challenging and complex process that requires evaluation of many diverse criteria, alongside with geospatial analysis. The identification of the living cost component of LCG is the first step in tackling the LCG challenge. Comprehensive studies to detect LCG in the EU Member States (MS) seem to be largely missing.

The multi-criteria spatial decision support techniques have been chosen for the purpose of this study, since they allow multiple criteria-based ranking of MS by using tightly integrated [37] geographic information systems (GIS) and multiple criteria decision-making (MCDM) approaches, along with general decision support input concerning analytical approaches and interpretations.

The overall purpose of this study is therefore to:

1. Develop flexible LCG identification framework, which could help decisions-makers in preparation of LCG mitigation measures;

2. Identify LCG change trends across MS;

3. Provide solution to identify which criterion (and under which circumstances) become more important for identification of LCG;

4. Estimate and evaluate relationship between compound annual growth rates (CAGR) of LCG and CAGR of each criterion, across MS. 


\section{Materials and Methods}

\subsection{Study Area and Source Data Preparation}

Open and publicly available data from Eurostat and World Bank for the period 2008-2017 (Table A1) were used for the identification of LCG in the $28 \mathrm{MS}$, assessed in this study and to create the composite LCG indicator.

The methodology comprised of 27 Eurostat [41-53] and 2 World Bank [54] indicators (called "criteria" in our study) at national level that were aggregated and processed in order to assess the LCG in the MS and consequently, to allow for comparison of LCG across MS.

For further analysis, all criteria were grouped based on criteria relationship with the households. Four criteria and household relationship types were defined and applied for grouping:

- Hypothetical distance from household: adjacent, neighbouring, and distant;

- Economic decision scale relationship with household: micro, mezzo, macro;

- Location effect on household: local, national, international;

- Impact of decision makers on household: individual, external.

Criterion and household relationship type can be described by spatial-temporal means. The criteria that might be impacted by decisions made at household level (e.g., net income, savings) are more adjacent than the criteria that cannot be impacted by decisions made at household level with immediate effect (e.g., labour market, gross domestic product (GDP), trade flows, etc.) on living standards.

Based on the relationship type, we grouped these determinants (criteria) into three categories (Table A2), as follows:

- Adjacent-micro-local-individual (e.g., household net earnings, savings);

- Neighbouring-mezzo-national-external (e.g., GDP, labour market, housing availability);

- Distant-macro-international-external (e.g., migration, remittance flows, trade flows);

Adjacent-micro-local-individual group was subsequently broken down into further three sub-categories (Table A2), as follows: income, basic, and optional expenditures;

Criteria grouping enabled separate evaluation and objective function definition (addressing the highest LCG) for each criterion (Table A2).

The overall input data preparation was orchestrated in order to find the highest LCG across MS, detect changes in LCG between 2008 and in 2017 respectively (Table A2), and find the indicators that impact LCG the most.

\subsection{The LCG Assessment Framework}

The objective criterion importance [55] has been calculated based on selected minimization/maximization functions. The function to maximize/minimize has been called "objective function." Criterion importance values (Table A3) have been then used as an input for the ranking of MS using simple additive weighting (SAW) and technique for order preference by similarity to ideal solution (TOPSIS) techniques [38]. The two methods have been applied for result validation reasons and also because they employed the same inputs, but via two different ranking approaches. The ranking outcomes have been considered reliable if both methods had generated similar results. The final SAW and TOPSIS values ranged from 0 (worst) to 1 (best) and altogether built the so-called composite LCG indicator. A higher rank value means higher LCG. The SAW and TOPSIS values for each MS have been separately calculated for 2008 and 2017 (Tables A4 and A5) and later compared with each other.

The so-identified composite LCG and LCG changes were visualized on a map by using quartile mapping technique to facilitate LCG comparisons amongst countries. In order to better understand which criterion had the strongest impact on LCG change, we calculated compound annual growth rates (CAGR) [56] of SAW (Table A4), TOPSIS (Table A5), and for all criteria (Table A6). Finally, we checked 
the relationship (Pearson correlation) between CAGR of each criterion and CAGRs of SAW (Table A4) and TOPSIS (Table A5) across MS (Table A6).

A Unified Modelling Language [57] based sequence diagram illustrates workflow and describes all data and information flows within the framework (Figure 1).

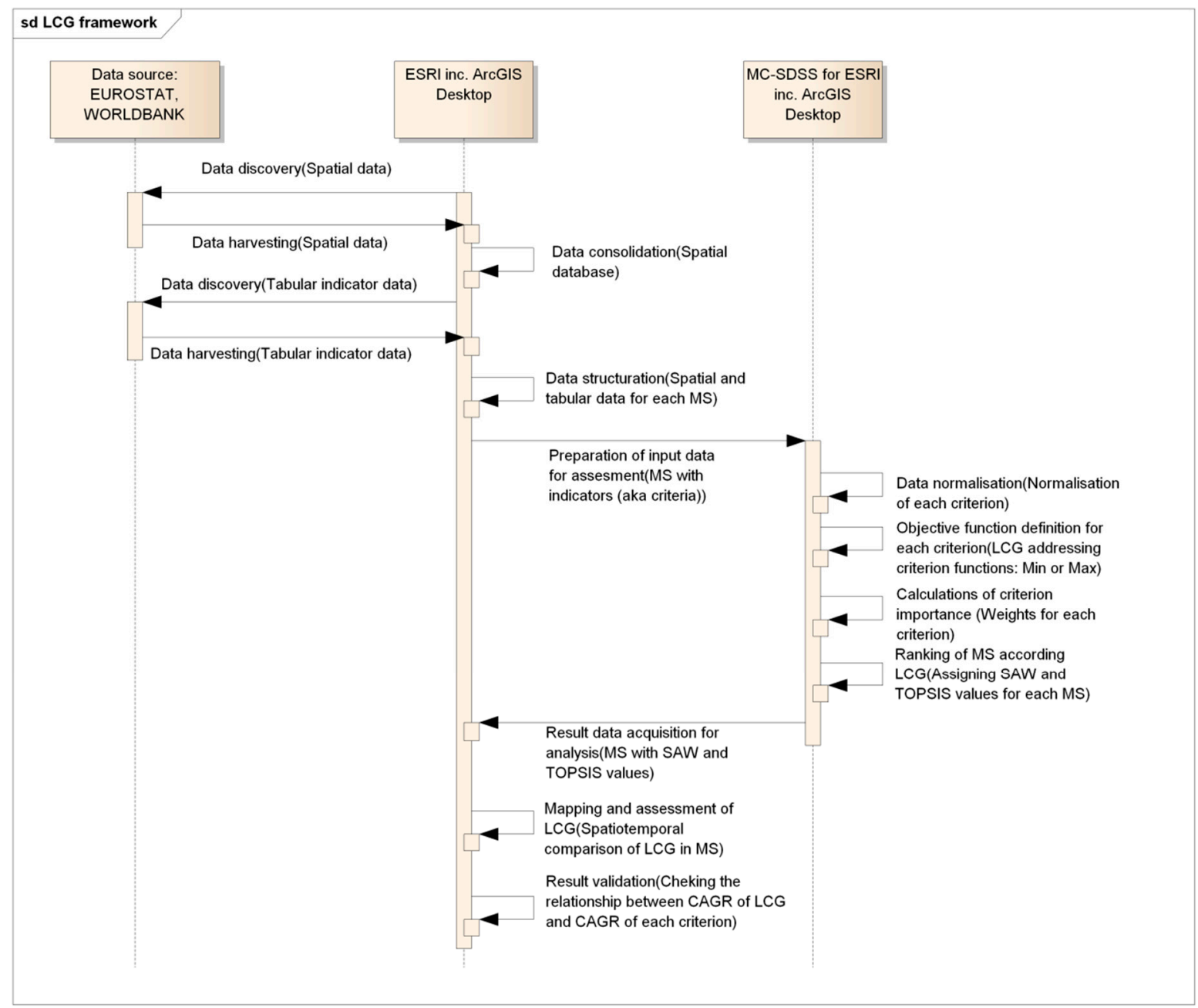

Figure 1. Decision flowchart for multiple criteria analysis of LCG.

The advanced level license of ArcGIS Desktop version 10.6 software developed by ESRI Inc., Redlands, CA, USA, has been applied for data analyses and mapping. To calculate the objective importance of criteria and country's LCG ranks, a custom SDSS [58], MC-SDSS for ArcGIS software extension [55], has been used (Figure A1). This extension implements full decision-making workflow (Figure A2) including calculation of criteria importance, SAW, and TOPSIS values within GIS environment.

\subsection{Definition of LCG Using Objective Functions}

A Unified Modelling Language [57] based sequence diagram illustrates workflow and describes all data and information flows within the framework (Figure 1).

Household management decisions are typically guided by multiple objectives measured in a range of financial and non-financial criteria. In order to perform ranking of MS, the importance of every criteria has been calculated (Table A3) based on the defined objective function that addresses the LCG issue (Table A2). 
We assume that LCG is the highest where the following criteria (Table A1) and its objective functions (minimization/maximisation) have been presented simultaneously across the MS (criteria grouping according Table A2):

i. Households with lowest (minimisation) net income and lowest savings;

ii. Households with highest (maximisation) expenditures on basic needs (housing, food, and transport) to maintain a minimum level of survival only;

iii. Households with lowest (minimisation) expenditures on optional needs (education, health, clothing, other miscellaneous goods, etc.);

iv. Households that are exposed to few employment opportunities and low GDP. MS where unemployment, low work intensity, and income poverty rates are the highest (maximisation) and GDP is lowest (minimisation);

v. Households that are exposed to housing gap issues. MS where the housing cost overburden rate and the prevalence of rented houses are the highest (maximisation) and home ownership is the lowest (minimisation);

vi. Households exposed to socio-economic challenges that only partially depend upon MS. MS where immigration, import of goods (MS expenditure) and remittance inflow (households demand for external support) are the highest (maximisation) and where emigration, export of goods (MS income), and remittance outflow (support capacity for households outside the country) are the lowest (minimisation).

The detailed description of each indicator and its objective function (focusing on the "highest LCG") is provided in Table A2. To test the objective functions and the linkages amongst the criteria, a criteria importance calculation algorithm [55] has been applied.

\subsection{Calculation of Objective Criteria Importance}

Before calculating the criteria importance, we normalised the source data (Table A1) by adjusting values measured on different scales to a notionally common scale using objective functions. The higher the importance value $q_{i}$ [55], the more important the criterion is. All resulting criteria importance values (Table A3) then have to be tested. The sum of importance values for all criteria has to be equal to 1 . This is a mandatory condition for further ranking via SAW and TOSPIS methods.

In order to assess agreement (regarding LCG) amongst all criteria we used Kendall's [59] coefficient of concordance (Kendall's $W$ or $W$ ). $W$ ranges from 0 (no agreement) to 1 (complete agreement). If $W=1$, then all the criteria are unanimous. If $W=0$, then there is no overall agreement among the criteria regarding LCG and criteria values may be regarded as random. Intermediate values of $W$ indicate greater or lesser degree of unanimity among various criteria considered (Table A3).

In our study, $W=0.001$ (for all criteria in Table A3) shows that criteria are still valid, but, there is no overall agreement among the criteria regarding LCG. All criteria selected are essentially random (might be also conflicting) and can be used for LCG identification across MS using SAW and TOPSIS methods, because these two different methods are dedicated to cope with conflicting criteria. The calculation of objective criteria importance values (including data normalisation and $W$ ) for each period was performed using original objective criteria importance calculation algorithm [55] implemented within custom made MC-SDSS for ArcGIS extension [55].

\subsection{Calculation of LCG Using SAW Method}

The SAW method $[38,60]$ is a multiple-criteria decision-making technique consisting of assigning to each alternative a sum of values, each one associated to the corresponding evaluation criterion, and weighted according to the relative importance of the corresponding criterion. The final SAW value is calculated by summing up all the weighted criteria for certain alternatives. The input data used for SAW calculations: MS as alternatives, normalised Eurostat, and World bank data as criteria and criteria importance values (Table A3). 
The alternative (certain MS amongst all MS) that best fit the objective function (highest LCG) is the one with the highest SAW value. MS with the lowest SAW values fit objective function (highest LCG) the least, which means that such MS have lowest LCG (Table A4).

\subsection{Calculation of LCG Using TOPSIS Method}

TOPSIS [38] defines a "similarity index" (relative proximity) by combining the geometric proximity to the positive-ideal solution and the remoteness of the negative-ideal solution. The alternative that fits the objective function (LCG) the best should have the shortest distance from the positive-ideal solution and the longest distance from the negative-ideal solution. The input data used for calculations is the same as in case of the SAW method that is described earlier.

The alternative (certain MS amongst all MS) that best fit the objective function (highest LCG) is the one with the highest TOPSIS value. MS with the lowest TOPSIS values fit objective function (highest LCG) the least, which means that such MS have lowest LCG (Table A5).

The calculation of SAW and TOPSIS values for each period and for each MS was performed using SAW and TOPSIS calculation algorithms $[38,60]$ implemented within custom made MC-SDSS for ArcGIS extension [55].

\section{Results}

\section{LCG and LCG Change Trends}

The analysis was focused on identifying the temporal LCG change within and across MS. In order to address the LCG changes, we identified the LCG for the MS within the 2008-2017 period (Tables A4 and A5) by calculating SAW and TOPSIS values on annual basis. The maps show the SAW and TOPSIS values (composite LCG indicator) for the baseline year 2008 (Figure 2A,B) and for the final year 2017 (Figure 3A,B).

According the findings from (Figure 2A,B), the highest LCG in 2008, estimated along both methods, was observed in two geographical parts of the EU-the Baltic Sea area (Latvia, Lithuania, and Poland) and the Black Sea area (Romania and Bulgaria), while the lowest LCG was revealed in a more scattered pattern, namely in Finland, Ireland, the Netherlands, Luxembourg, Austria, and Cyprus. It is worth nothing that Belgium, Germany, Hungary, Croatia, and Greece appear also as countries with rather high LCG. Combined with the results for the very high LCG, these observations mean that the whole Eastern wing of the EU (except Cyprus), generally suffered of substantial LCG pressure in 2008. On the other hand, Spain, Malta, Italy, Slovenia, and Denmark were peculiar with relatively low LCG. The picture for the remaining EU countries assessed-Sweden, Estonia, Czechia, Slovakia, France, the United Kingdom, and Portugal—was mixed. The following additional conclusions about LCG by 2008 could be thereby revealed:

- Estonia was more similar to Finland, rather than to the other two Baltic States;

- The situation in the Benelux area was very diverse;

- Czechia and Slovakia were rather similar;

- The Southern layer of the EU, which in other contexts is often put together and demonstrates similarities, was very distinct. 

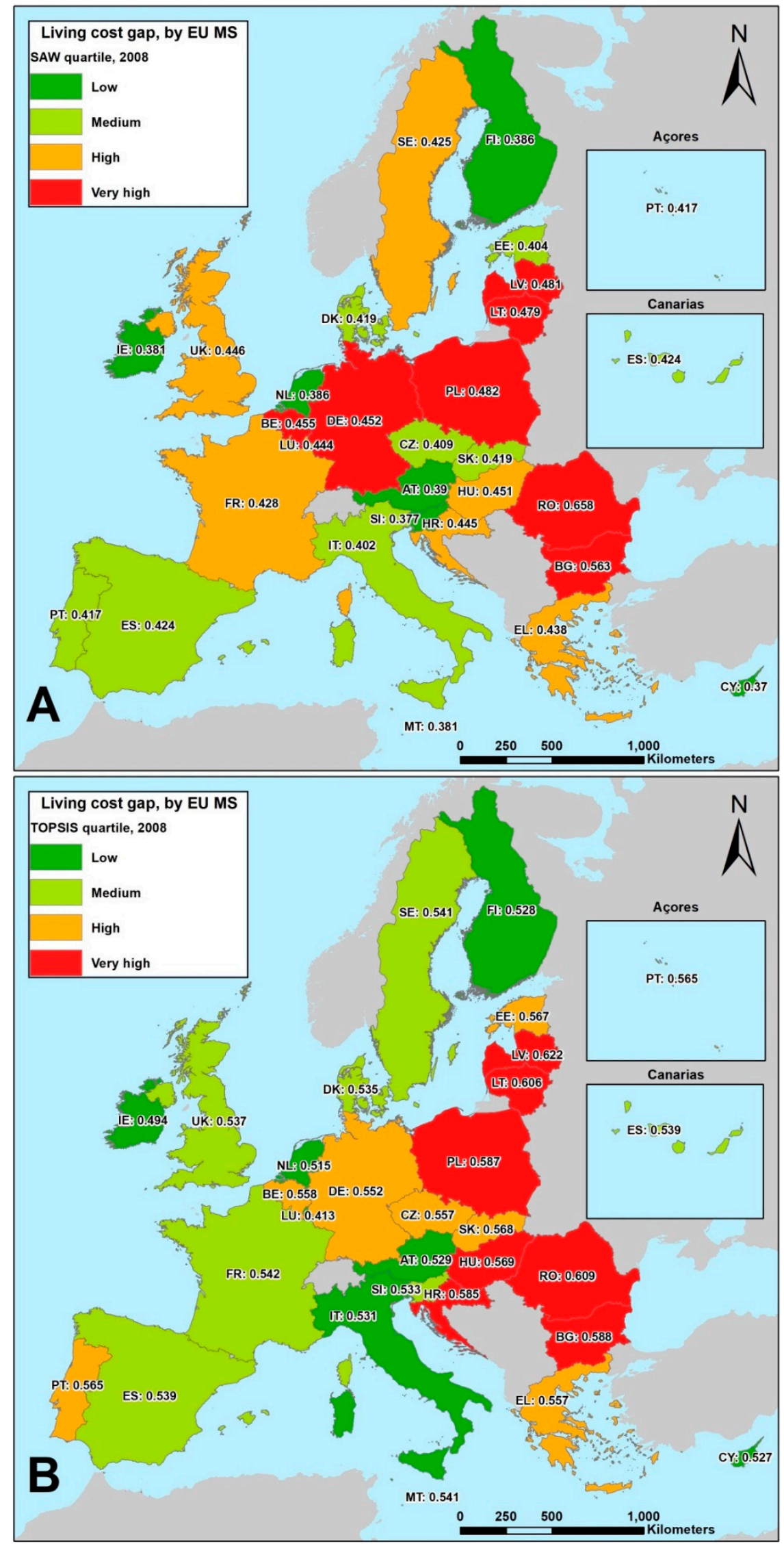

Figure 2. Quartile map of composite LCG indicator expressed in SAW (A) and TOPSIS (B) values for 2008 within the EU. Map labels display: MS name abbreviation, SAW value (A), and TOPSIS value (B). 

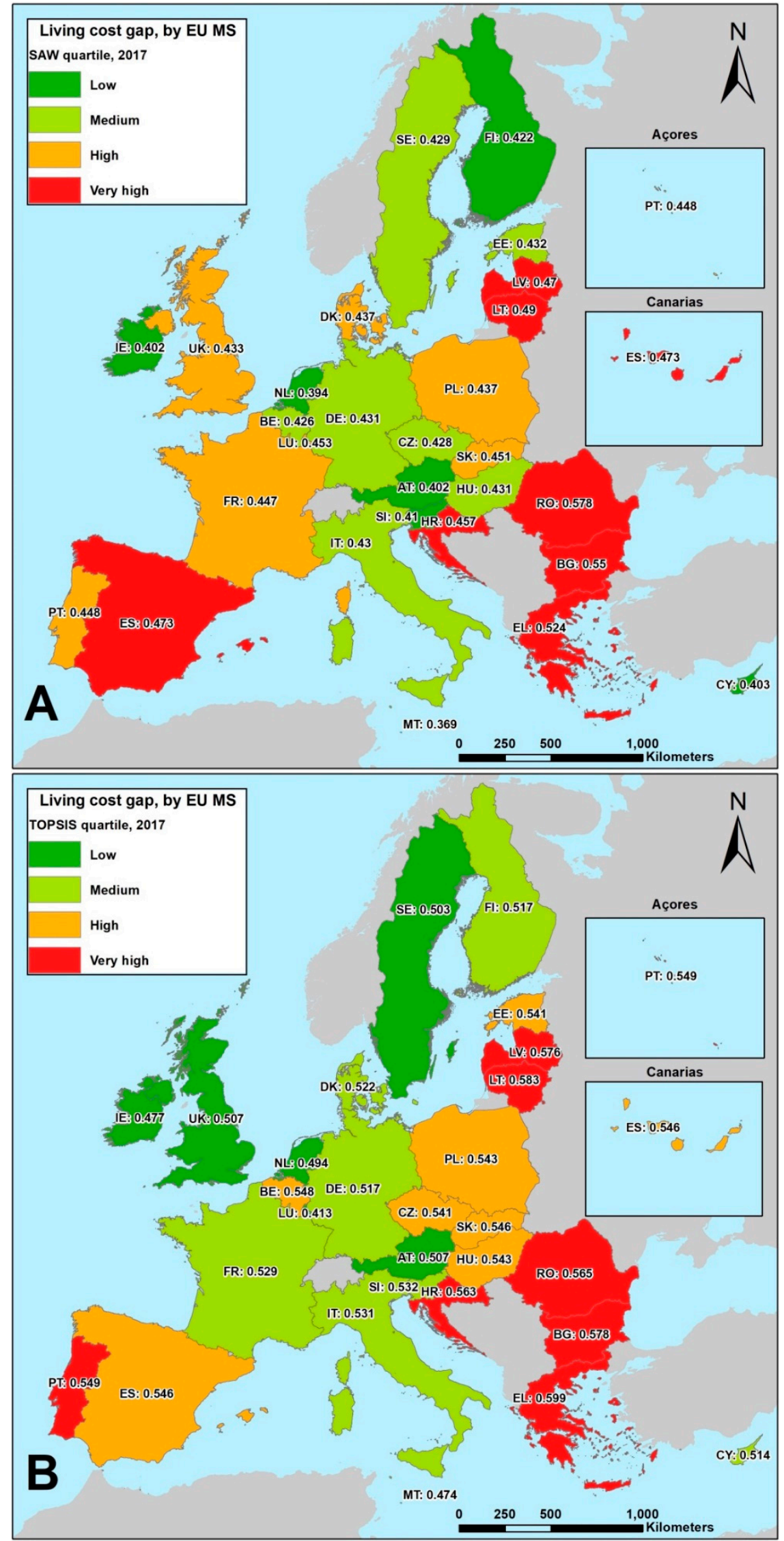

Figure 3. Quartile map of composite LCG indicator expressed in SAW (A) and TOPSIS (B) values for 2017 within the EU. Map labels display: MS name abbreviation, SAW value (A), and TOPSIS value (B). 
In 2017, the group of the countries with the highest LCG (Figure 3A,B) did not undergo major modifications and again the two Baltic States (Latvia and Lithuania) and the two Black Sea EU members (Romania and Bulgaria) landed there. Poland improved a little bit and went up to the group of high LCG, but Greece and Croatia worsened and joined the club of the MS with the highest LCG. In such a way, the very high LCG class got concentrated in the South-eastern wing of the EU, located on the Balkan Peninsula. At the other end — the group of the lowest LCG—-there were no major changes either. Ireland, the Netherlands, Luxembourg, and Austria retained their membership. The downward LCG change for Finland and Cyprus was negligible, while another small MS, Malta, substituted Cyprus in this group. The LCG situation on the Iberian Peninsula (Portugal and Spain) worsened, while it improved in Belgium, Germany, Poland, Hungary, Sweden, and to some extent in the United Kingdom. The remaining MS assessed (France, Italy, Slovenia, Czechia, Slovakia, Denmark, and Estonia) did not change much their relative LCG ranking.

Besides the above relative ranking, the absolute LCG values, revealed along both SAW and TOPSIS methods, suggests a more balanced situation across the EU. No extreme values ( 0 or 1$)$ were ever detected in any MS. The LCG values ranged between 0.38 and 0.66 both for 2008 and 2017, i.e., around the mean of 0.5 ( -0.13 and +0.16 respectively to the mean). This observation means that LCG existed as a phenomenon even in the best performing (in terms of LCG) countries, but, on the other hand, there were no MS really facing a dramatic LCG challenge. The similar ranges of SAW and TOPSIS values also indicates that that so-revealed results are reliable, especially in the extreme cases, while the sensitivity is obviously greater in the middle of the sample. Altogether, these findings imply with quite some certainty that the LCG issue was relatively moderate in the EU both in 2008 and 2017.

\section{Discussion}

\subsection{Possible Framework Advantages and Drawbacks}

Combining 29 indicators from different sources (Table A1) into a single multidimensional composite indicator allows identifying the LCG, which otherwise would not be feasible by analysing those 29 indicators separately. The composite LCG indicator therefore reveals more comprehensively the critical LCG across the EU than the separate statistical indicators alone.

The basic variable inputs for both methods were the same, but different standardization/weighting techniques might have led to slightly different results [61]. Ranking process could have resulted in situations where certain criteria might have increased ambiguities in the decision-making process due to insufficient information or contradicting judgments [61-63].

The application of SAW and TOPSIS techniques should be more careful when a large number of criteria are used. A high number of criteria in one assessment reduces and somehow equalises criterion importance. In such a case, the solution matrix might become very sensitive and the results-not plausible, since a small change in weighting and/or an error in observation data might result in very sensitive ranking and consequently-alter the whole evaluation and ranking.

In our study, LCG was calculated by employing the SAW and TOPSIS methods. Both methods are fairly simple and appear as the most widely used multi-attribute decision techniques. The tightly integrated GIS and MCDM components [40] allowed to run calculations simultaneously, share a common database (Figure A2), and perform immediate analysis because the programme control remained within the GIS when performing the MCDM analysis.

We found that both SAW and TOPSIS methods were most accurate for the MS with the highest and lowest LCG. In the remaining, more moderate cases, the LCG, calculated via SAW, was always increasing (Table A4), while the LCG calculated along TOPSIS was decreasing (Table A5). It was because the TOPSIS method is generally more accurate than the SAW method in calculating distances from the extreme (best or worst) options [61].

The results from our study can be interpreted at the national level only. The proposed framework can be applied in the future also for LCG analyses at finer disaggregation (regional, 
local, city/urban) level by ingesting additional socio-economic historic data and projections from the European Commission's LUISA Territorial Modelling Platform [64], backed up by the Urban Data Platform (UDP) [65] and/or other relevant data and information sources available at a more local level. The corresponding results and interpretation will obviously depend on the input data scope, coverage, quality, respective modifications and adjustments of the objective function, temporal accuracy and coherence, and finally-disaggregation levels.

\subsection{Criteria Importance Definition and Assessment}

In order to address the LCG, we computed objective criteria importance based on input data distribution and scattering [55]. It is recommended to exclude similar indicators from the same assessment. Strongly or perfectly positively correlated (Pearson) criteria might also be redundant and should be excluded from multi-attribute analysis, because they may lead to misleading interpretations, especially when the same objective function is applied for perfectly correlated criteria. In our case, we used (with few exceptions) indicators that had negligible or moderate correlations. The strongest (indeed-perfect, $r=-1$ ) negative correlation was found between homeowners and home tenants, followed by household expenditure on food and net household income $(r \sim-0.9)$. The strongest positive correlation was revealed between household net income and GDP $(r \sim 0.9)$. We further analysed those three indicators because we assumed that LCG could not be evaluated without household income and basic expenditures, while GDP was the only macro-economic criteria in the overall assessment. For the contradictory indicators with tenure status (tenants vs. homeowners), we applied different objective functions. The other indicators demonstrated negligible-moderate relationships.

\subsection{Detailed Analysis of Changes in LCG}

The minimum and maximum SAW and TOPSIS values in 2008 and 2017 from (Figures 2 and 3) are depicted in Figure 4.

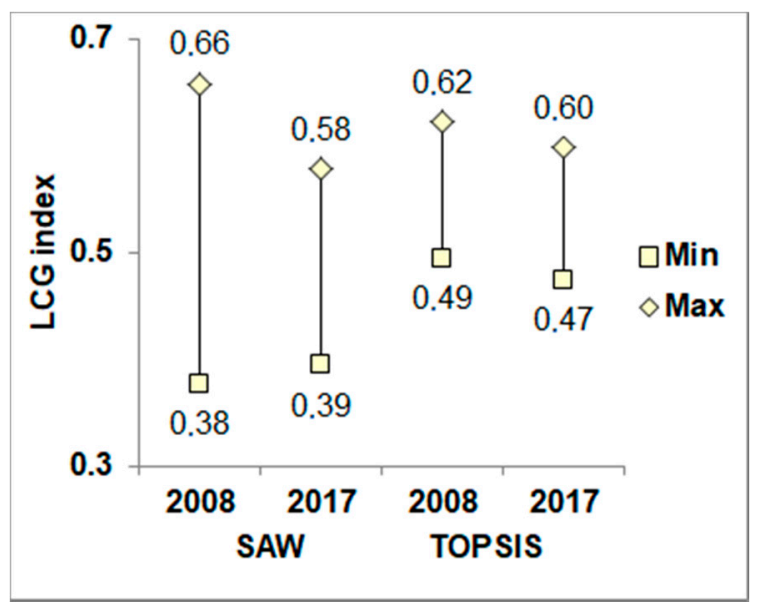

Figure 4. Minimum and maximum SAW and TOPSIS values of LCG in the EU by MS in 2008 and 2017. Black lines illustrate distances between highest and lowest values.

Based on our findings (Figure 4), the following conclusions at EU level can be drawn:

- With one single exception (the maximum value for 2017), the SAW method tended to generate lower minimum value and higher maximum values than the TOPSIS method. As a result, the gap between minimum and maximum values under the SAW method was constantly larger than the one under the TOPSIS method.

- Under both methods, the gap between minimum and maximum values got smaller in 2017 compared to 2008. This means that the LCG divergence across the EU decreased, i.e., some kind of pan-EU LCG convergence occurred. Under the SAW method, the convergence was due to a 
significant decrease in the maximum LCG value, which compensated for the slight increase in the minimum LCG value. Under the TOPSIS method, the shrinking gap was due to a parallel moderate decline in both minimum and maximum LCG values.

At the country level (Figure 5), the detailed results indicate that within 2008-2017 the LCG definitely shrank in ten assessed MS: the United Kingdom, Belgium, Luxembourg, Germany, Poland, Latvia, Hungary, Romania, Bulgaria, and Malta. The LCG cutback was particularly important for Latvia, Romania, and Bulgaria, which countries ended up in the group of the largest LCG both in 2007 and 2018. This means that although the LCG remained a significant challenge for those countries, some improvements took place between 2008 and 2017. With regard to the other MS in this group, it is worth also noting the substantial improvement of LCG in Germany, which made it up from the third (high LCG) and even the fourth (very high LCG) quartile in 2008 to the second (moderate LCG) quartile in 2017.

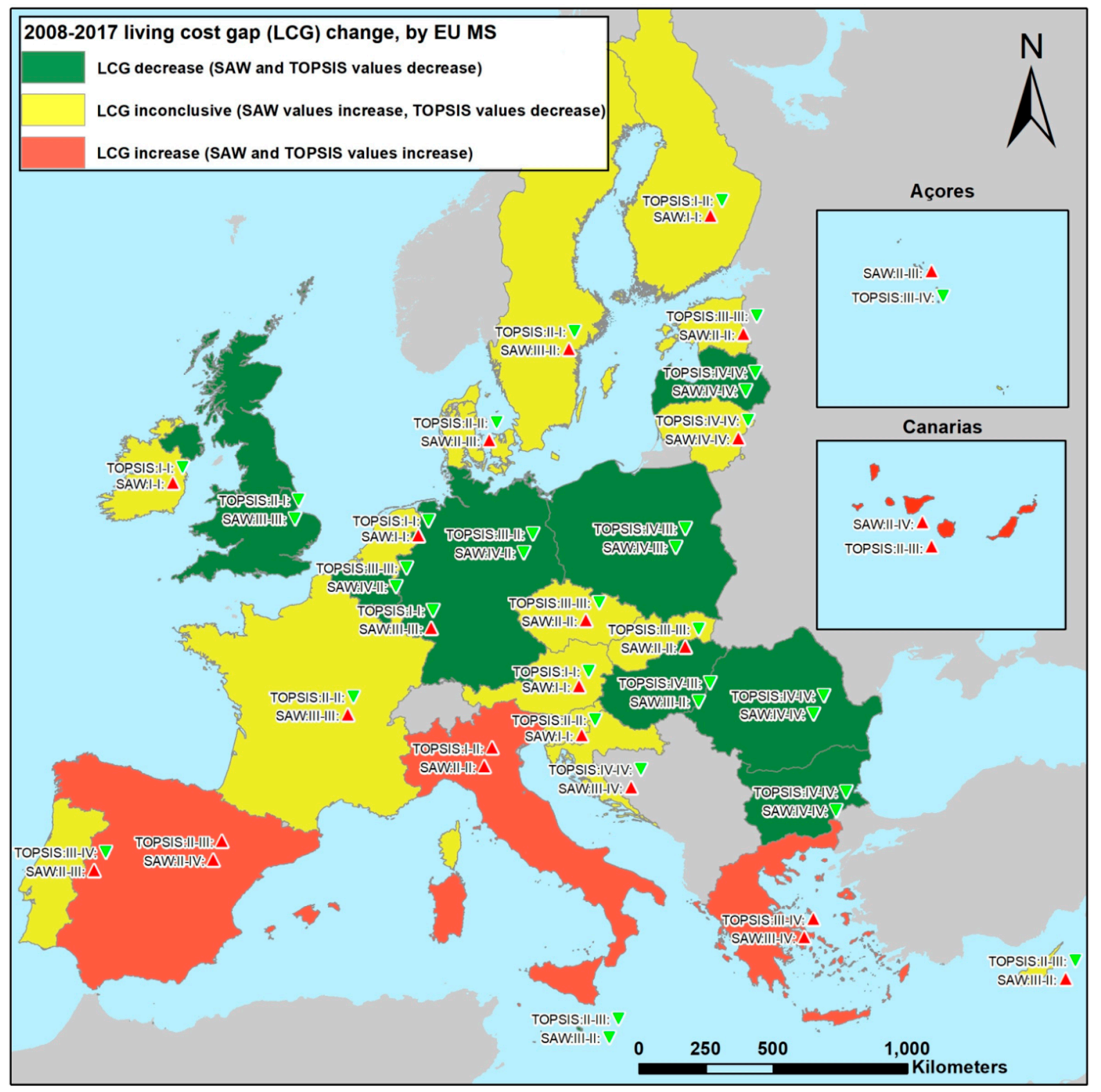

Figure 5. Change of LCG (2008-2017) across the EU MS. Map labels with Roman style numerals display SAW and TOPSIS quartile values for 2008 in the left and for 2017 at the right side of the hyphen (-). Quartile I-means the lowest LCG while quartile IV means the highest LCG. Red arrows $\Delta$ show increase and green arrows $\mathbf{v}$ show decrease of both SAW and TOPSIS values (LCG) in 2017 compared to 2008. 
At the other end, i.e., the group of MS where the LCG clearly expanded over the period 2008-2017, landed Greece, Italy, and Spain, the countries that were hit maybe the most by the financial and economic crisis in 2008-2009. The LCG values from Figures 2 and 3 suggest that the LCG expansion was the most pronounced in Spain, which shifted from the second (moderate LCG) quartile in 2008 to the third (high LCG) and the even fourth (very high LCG) quartile in 2017. Spain was followed by Greece that descended from the third (high LCG) quartile in 2008 to the fourth (very high LCG) quartile in 2017. Amongst those three MS, Italy was the least affected by the downward trend in LCG, because the LCG levels were relatively low in both 2008 and 2017 and hence, in 2017 the country firmly landed in the second (moderate LCG) quartile.

\subsection{The LCG Roots}

The calculations showed that the objective criteria importance did not change much over the years, considering that input data distributions remained uniform/constant (Table A3). The indicator on household savings turned out to be the most important one $\left(q_{i}=0.036\right)$ for LCG (Table A3) during the period 2008-2017. This is because household savings criterion values were the most scattered [66] compared to the other criteria values included in the LCG assessment.

During the 2008-2011 period, the immigration criterion was equally important $\left(q_{i}=0.036\right)$ as household saving. The importance of immigration in that period was higher compared to the one in the following period 2011-2017. The objective function on immigration was set to minimisation, i.e., we looked for the MS with the lowest immigration rates. The reasoning of this objective function suggested (Table A2) that the economic situation in MS (to host the migrants) was tough and migrants (especially the economic ones) could not earn decent income and savings (Table A2). The high initial importance of that criteria could be possibly explained by the financial and economic crisis of 2008-2009 and the following recovery in the MS, which had little to offer to the migrants, especially to the economic ones. Consequently, the criterion indicated higher LCG, but it did not explain the driving reasons behind.

Indicators of relatively lower importance (medium scattering) were revealed: net household income, GDP, remittances, migration (except, as already explained, the migration in the initial period 2008-2011), imports, and optional household expenses on education, restaurants, and miscellaneous goods.

Least important (least scattered) criteria were identified: exports, low work intensity, risk of income poverty, unemployment, tenure status, and household expenditure on other needs (besides education, restaurants, and miscellaneous goods) Table A3.

In order to comprehensively address the LCG, we introduced all indicators (Table A3) and their importance into multi-criteria analyses.

\subsection{LCG Drivers}

We did not aim to measure income inequality [67], poverty [68,69], the households' quality of life [70], or other phenomenon describing social and economic well-being [71] across the MS. The goal of the composite multidimensional LCG indicator was to identify core criteria impacting living cost gap across the MS. This indicator shows how large/small the living cost gap is (distance wise), but it does not explain how good or bad the living cost situation is.

Following our results, SAW and TOPSIS outcomes suggested that ranking results (Tables A4 and A5) were ambiguous and inconclusive for the second and third quartiles (Figure 5). The correlation between CAGRs of SAW and TOPSIS values was moderate $(r=0.72)$ and thus, it could be considered as moderately reliable for the highest (fourth quartile) and lowest (first quartile) ranks (Figure 5) where both methods had shown the same results. 
In order to understand how criteria changes were relating with LCG change across MS, we analysed the relationship between CAGR [56] of each indicator with CAGRs of SAW (Table A4) and TOPSIS (Table A5). The CAGR is defined as:

$$
\operatorname{CAGR}\left(t_{0}, t_{n}\right)=\left(\frac{V\left(t_{n}\right)}{V\left(t_{0}\right)}\right)^{\frac{1}{\mathrm{t}_{\mathrm{n}}-t_{0}}}-1
$$

where $V\left(t_{0}\right)$ is the initial value, $V\left(t_{n}\right)$ is the end value, and $t_{n}-t_{0}$ is the number of years. The actual values have been used for calculations.

The value of $r$ (Pearson correlation index) lies between (-1) and (1), inclusive (Figure 6). That is, $-1 \leq r \leq 1$. If $r$ took positive value, the variables were positively correlated. If $r$ took negative value, the variables were negatively correlated. If $r$ took the value 0 , then there was no relationship between the CAGRs of indicators and CAGRs of SAW and TOPSIS (LCG). In our study, we used interpretation of $r$ as: 0 -no association; 0 to 0.25 ( 0 to -0.25$)$-weak association; 0.25 to 0.50 ( -0.25 to -0.50$)$-moderate association; $0.50-0.75$ ( -0.50 to -0.75$)$ - strong association; 0.75 to 1.00 ( -0.75 to -1.00$)$-very strong association; and $1(-1)$-perfect association [72].

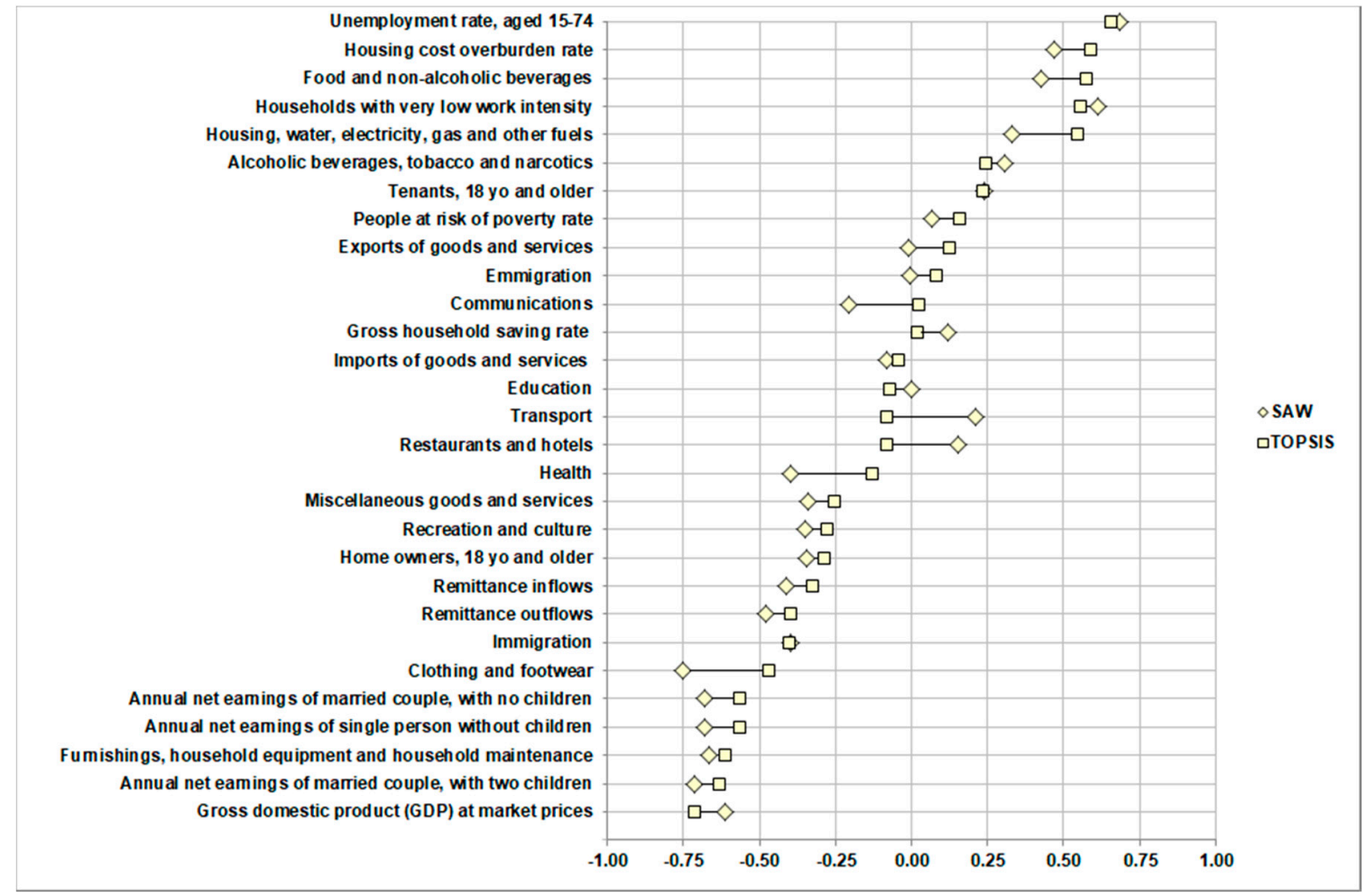

Figure 6. Pearson correlation values between CAGR of each indicator and CAGRs of SAW (Table A4) and TOPSIS (Table A5), across all MS (Table A6). Black lines illustrate distances between correlation values.

The relationship (Pearson correlation coefficient) between SAW and TOPSIS CAGRs values was strong $(r=0.72)$ which re-confirmed the that both methods showed the same trends (not perfect, but reliable) of LCG across MS. Pearson correlation coefficients also revealed the relationship between CAGRs of SAW and TOPSIS with CAGRs of all criteria (Figure 6). Negative coefficient values meant opposite trends, i.e., increased values in one array and decreased in another one. Positive values indicated parallel trends, i.e., the values in either arrays increased or decreased at the same time. Simultaneous growth of SAW and TOPSIS values predisposed escalating LCG.

The correlation analyses (Figure 6) of CAGRs revealed that CAGR of LCG grew when CAGRs of the following indicators across MS rose: 
- With strong positive relationship: unemployment and low work intensity;

- With moderate positive relationship: housing cost overburden and basic household expenditures, i.e., food, housing;

- With weak positive relationship: house tenants, risk of income poverty, exports, and optional household expenditures (alcoholic beverages, tobacco).

The correlation analyses of CAGR s revealed that CAGR of LCG expanded when CAGRs of following indicators across all MS decreased:

- With strong negative relationship: GDP (in line with [66]), all types of net household earnings, household expenditure on optional needs (furnishing and clothing);

- With moderate negative relationship: immigration, remittance flows, home ownership, optional household expenditures (recreation and miscellaneous);

- With weak negative relationship: household savings, imports, optional household expenditures (communications, education, transport, restaurants, and health).

Household income and expenditures constantly increased across the large majority of MS within 2008-2017. There was, however, a strong negative relationship (correlation) between LCG and household income. In order to shrink LCG (in the countries where TOPSIS and SAW values were the highest) it is necessary to focus on balancing "income and wealth effects" [66,73,74], increasing household saving rate and directing savings to support household basic needs rather than onto acquisition of financial and/or non-financial assets, i.e., converting them into "investment vehicles" [75].

\subsection{LCG and Housing}

The notion "Housing" can be defined as differential amongst tenure type, housing cost/affordability, crowding, and quality $[7,76,77]$. Our study shows that the largest expenditure of the average households was on housing and amounted to more than $20 \%$ of the net household income during the period 2008-2017 (Table A1). More specifically, the average net household expenditures on housing was $\sim 21.0 \%$ in 2008 and $21.8 \%$ in 2017 (with the highest peak of 22.7\% in 2013) across the MS. The highest (in the range of $25-30 \%$ ) average household expenditure on housing was observed in Czechia, Denmark, France, Slovakia, Finland, Sweden, and the United Kingdom. At the other end, the lowest (in the range of 10-20\%) average household expenditure on housing was recorded in Bulgaria, Estonia, Croatia, Cyprus, Lithuania, Malta, Portugal, and Slovenia. The largest decrease (CAGR 2008-2017) in household expenditures on housing occurred in Malta, Cyprus, Hungary, and Germany, while an increase was registered for Finland, Portugal, Netherlands, Bulgaria, Spain, and Luxembourg (Table A6).

The CAGR of household expenditure on housing (2008-2017) tended to slightly increase in parallel with the rise in CAGR of unemployment, low work intensity, risk of income poverty, housing cost overburden, home rentals, savings, food, health, and remittance inflows. The CAGR of household expenditure on housing tended to decrease with the growth in CAGR of household expenditure on optional needs (except health), transport, net income, home ownership, trade, migration, and GDP remittance outflows (Table A6).

Based on the above findings, we can conclude that household expenditure on housing increased when household expenditure on other basic needs also grew, while household expenditure on housing shrunk when household income and expenditure on optional needs grew. In the MS where household net income was higher (e.g., Luxembourg, the Netherlands, Germany Sweden, the United Kingdom, Denmark, Belgium), the rest of household expenses (after expenses on housing) were dedicated to optional needs and savings. In the MS where household net income was lower (e.g., Lithuania, Bulgaria, Romania, Latvia, Hungary, Poland, Croatia, Czechia, Estonia), the rest of household expenses were dedicated to basic needs without (e.g., in the case of Lithuania, Latvia, Bulgaria,) or with minimum savings (Table A6). 
Ultimately, the CAGR of housing cost overburden rate had a positive moderate (SAW) to strong (TOPSIS) relationship (Table A6) with CAGR of SAW and TOPSIS values (LCG indicator). This is a logical conclusion that re-confirms the reliability of the so-obtained LCG ranking results. When confronted with housing cost overburden, households can adapt by reducing their housing consumption via accepting smaller space and lower quality standards $[7,78]$.

\section{Conclusions}

The LCG describes the difference between the income that households earn and what they need to live. Household net income slowly but constantly increased in the majority of MS within 2008-2017. In most cases, the household expenditures also increased and hence, the relatively scattered household savings did not change significantly during the same period of time.

LCG was more prevalent in those MS where households were exposed to higher levels of unemployment, low work intensity, higher housing cost overburden, and higher expenditures on basic needs. Our research highlights the needs to mitigate unemployment and low household net income to narrow LCG across the MS.

Increasing household expenditures on basic needs (food, housing, and transport) in households with lower net income brought rise in LCG. The highest LCGs were found in those MS where household incomes were the lowest. The LCG was lower in those MS where GDP, immigration, household income, and household expenditure on optional needs and home ownership were higher.

Income and expenses constantly increased across all MS from 2008-2017. There was, however, a moderate relationship between LCG and household income.

In order to narrow LCG in those countries where LCG were the highest, it is necessary to significantly increase household income and income options, while at the same time look for reserves to boost household savings. Poorer households cannot, however, benefit much from negligible income growths due to the parallel rise in living costs.

Conversely, in order to maintain low or even decreasing LCG, it might be useful to upkeep constant growth of household net income and household savings.

The elaborated methodology might be applied to mitigating LCG by employing also other social-economic criteria at different spatial-temporal scales. Further research might include more high-resolution data to refine the LCG estimates at higher spatial scale such as: cities, towns, suburbs, and even-rural areas.

Author Contributions: Conceptualization, A.K.; methodology, A.K. and B.K.; software, A.K.; validation, A.K.; formal analysis, B.K.; investigation, B.K.; resources, C.L.; data curation, A.K.; writing-original draft preparation, A.K.; writing-review and editing, B.K.; visualization, A.K.; supervision, C.L.; project administration, C.L.; funding acquisition, C.L. All authors have read and agreed to the published version of the manuscript.

Funding: This research received no external funding.

Acknowledgments: The authors would like to sincerely thank to Carolina Perpiña Castillo, Paola Proietti, Jean-Philippe Aurambout and Filipe Batista e Silva for their thorough comments and helpful suggestions that have resulted in a much-improved version of this manuscript.

Conflicts of Interest: The authors declare no conflict of interest.

Disclaimer: Responsibility for the information and views set out in this paper lies entirely with the authors. More specifically, the scientific output expressed does not imply a policy position of the European Commission. Neither the European Commission nor any person acting on behalf of the Commission is responsible for the use that might be made of this publication. 


\section{Appendix A}

Table A1. Eurostat and World Bank data (2008-2017) metadata.

\begin{tabular}{|c|c|c|c|}
\hline No. & Indicator/Criterion Name ${ }^{1}$ & Unit of Measure & Brief Description \\
\hline 1. & Food and non-alcoholic beverages & \multirow{12}{*}{$\begin{array}{l}\text { Percentage of total household } \\
\text { expenditure }\end{array}$} & \multirow{12}{*}{$\begin{array}{l}\text { Household expenditure refers to any spending done by a person living alone or by a group of } \\
\text { people living together in shared accommodation and with common domestic expenses. } \\
\text { It includes expenditure incurred on the domestic territory (by residents and non-residents) for } \\
\text { the direct satisfaction of individual needs and covers the purchase of goods and services, } \\
\text { the consumption of own production (such as garden produce) and the imputed rent of } \\
\text { owner-occupied dwellings [41]. }\end{array}$} \\
\hline 2. & Alcoholic beverages, tobacco, and narcotics & & \\
\hline 3. & Clothing and footwear & & \\
\hline 4. & Housing, water, electricity, gas, and other fuels & & \\
\hline 5. & $\begin{array}{l}\text { Furnishings, household equipment and } \\
\text { routine household maintenance }\end{array}$ & & \\
\hline 6. & Health & & \\
\hline 7. & Transport & & \\
\hline 8. & Communications & & \\
\hline 9. & Recreation and culture & & \\
\hline 10. & Education & & \\
\hline 11. & Restaurants and hotels & & \\
\hline 12. & Miscellaneous goods and services & & \\
\hline 13. & Household savings & Saving percentage per household & $\begin{array}{l}\text { The gross saving rate of households (including Non-Profit Institutions Serving Households) is } \\
\text { defined as gross saving divided by gross disposable income, with the latter being adjusted for } \\
\text { the change in the net equity of households in pension funds reserves. Gross saving is the part of } \\
\text { the gross disposable income which is not spent as final consumption expenditure [42]. }\end{array}$ \\
\hline 14. & $\begin{array}{l}\text { Annual net earnings of single person without } \\
\text { children }\end{array}$ & Total EUR per capita & \multirow{3}{*}{$\begin{array}{l}\text { Information on net earnings (net pay taken home, in absolute figures) and related tax-benefit } \\
\text { rates (in \%) complements gross-earnings data with respect to disposable earnings. The transition } \\
\text { from gross to net earnings requires the deduction of income taxes and employee's social security } \\
\text { contributions from the gross amounts and the addition of family allowances, if appropriate [ } 43\end{array}$} \\
\hline 15. & $\begin{array}{l}\text { Annual net earnings of married couple with } \\
\text { no children }\end{array}$ & \multirow[t]{2}{*}{ Total EUR per household } & \\
\hline 16. & $\begin{array}{l}\text { Annual net earnings of married couple with } \\
\text { two children }\end{array}$ & & \\
\hline 17. & Housing cost overburden rate & Percentage of total population & $\begin{array}{c}\text { Percentage of the population living in a household where total housing costs (net of housing } \\
\text { allowances) represent more than } 40 \% \text { of the total disposable household income (net of housing } \\
\text { allowances) [44]. }\end{array}$ \\
\hline 18. & Tenants, 18 yo and older & \multirow{2}{*}{ Percentage of total population } & \multirow{2}{*}{$\begin{array}{c}\text { Distribution of population by a broad group of citizenship and tenure status (population aged } 18 \\
\text { and over) [45]. }\end{array}$} \\
\hline 19. & Homeowners, 18 yo and older & & \\
\hline
\end{tabular}


Table A1. Cont.

\begin{tabular}{|c|c|c|c|}
\hline No. & Indicator/Criterion Name $^{1}$ & Unit of Measure & Brief Description \\
\hline 21. & $\begin{array}{c}\text { Gross domestic product (GDP) at market } \\
\text { prices }\end{array}$ & Total EUR per capita & $\begin{array}{l}\text { The indicator is calculated as the ratio of real GDP to the average population of a specific year. } \\
\text { GDP measures the value of total final output of goods and services produced by an economy } \\
\text { within a certain period of time. It includes goods and services that have markets (or which could } \\
\text { have markets) and products which are produced by general government and non-profit } \\
\text { institutions. It is a measure of economic activity and is also used as a proxy for the development } \\
\text { in a country's material living standards. However, it is a limited measure of economic welfare. } \\
\text { For example, GDP does not include most unpaid household work nor does GDP take account of } \\
\text { negative effects of economic activity, like environmental degradation [47]. }\end{array}$ \\
\hline 22. & Households with very low work intensity & Percentage of total population & $\begin{array}{l}\text { People living in households with very low work intensity are people aged } 0-59 \text { living in } \\
\text { households where the adults work } 20 \% \text { or less of their total work potential during the past year } \\
\text { [48]. }\end{array}$ \\
\hline 23. & People at risk of poverty rate & Percentage of total population & $\begin{array}{l}\text { People at risk-of-poverty are persons with an equivalised disposable income below the } \\
\text { risk-of-poverty threshold, which is set at } 60 \% \text { of the national median equivalised disposable } \\
\text { income (after social transfers). The indicator is part of the multidimensional poverty index [49]. }\end{array}$ \\
\hline 24. & Remittance inflows ${ }^{1}$ & Total USD per capita & $\begin{array}{l}\text { World Bank staff calculation based on data from IMF Balance of Payments Statistics database and } \\
\text { data releases from central banks, national statistical agencies, and World Bank country desks [ } 54 \text { ]. }\end{array}$ \\
\hline 25. & Remittance outflows ${ }^{1}$ & & \\
\hline 26. & Emigration & Percentage of total population & $\begin{array}{l}\text { Total number of long-term emigrants leaving from the reporting country during the reference } \\
\text { year [50]. }\end{array}$ \\
\hline 27. & Immigration & & $\begin{array}{l}\text { Total number of long-term immigrants arriving into the reporting country during the reference } \\
\text { year [51]. }\end{array}$ \\
\hline 28. & Exports of goods and services & Percentage of GDP & $\begin{array}{l}\text { This indicator is the value of exports of goods and services divided by the GDP in current prices } \\
\text { [52]. }\end{array}$ \\
\hline 29. & Imports of goods and services & & $\begin{array}{l}\text { This indicator is the value of imports of goods and services divided by the GDP in current prices } \\
\text { [53]. }\end{array}$ \\
\hline 20. & Unemployment rate, aged $15-74$ & Percentage of active population & $\begin{array}{l}\text { The unemployment rate is the number of unemployed persons as a percentage of the labour } \\
\text { force based on International Labour Office (ILO) definition. The labour force is the total number } \\
\text { of people employed and unemployed. Unemployed persons comprise persons aged } 15 \text { to } 74 \\
\text { who are without work during the reference week, are available to start work within the next two } \\
\text { weeks, and have been actively seeking work in the past four weeks or had already found a job to } \\
\text { start within the next three months [46]. }\end{array}$ \\
\hline
\end{tabular}


Table A2. Objective function description addressing the LCG

\begin{tabular}{|c|c|c|c|}
\hline Criterion No. $^{1}$ & Objective Function Group & Objective Function (Focusing on Highest LCG) Explanation & Objective Function Defined \\
\hline 1 & ii. Adjacent-Micro-Local-Individual & Household expenditure on food (basic needs) is the highest. & MAX \\
\hline 2 & iii. Adjacent-Micro-Local-Individual & Household expenditure on alcoholic beverages (optional needs) is the lowest. & MIN \\
\hline 3 & iii. Adjacent-Micro-Local-Individual & Household expenditure on clothing (optional needs) is the lowest. & MIN \\
\hline 4 & ii. Adjacent-Micro-Local-Individual & Household expenditure on housing (basic needs) is the highest. & MAX \\
\hline 5 & iii. Adjacent-Micro-Local-Individual & Household expenditure on furniture (optional needs) is the lowest. & MIN \\
\hline 6 & iii. Adjacent-Micro-Local-Individual & Household expenditure on health (optional needs) is the lowest. & MIN \\
\hline 7 & ii. Adjacent-Micro-Local-Individual & Household expenditure on transport (basic needs) is the highest. & MAX \\
\hline 8 & iii. Adjacent-Micro-Local-Individual & Household expenditure on communications (optional needs) is the lowest. & MIN \\
\hline 9 & iii. Adjacent-Micro-Local-Individual & Household expenditure on recreation (optional needs) is the lowest. & MIN \\
\hline 10 & iii. Adjacent-Micro-Local-Individual & Household expenditure on education (optional needs) is the lowest. & MIN \\
\hline 11 & iii. Adjacent-Micro-Local-Individual & Household expenditure on restaurants (optional needs) is the lowest. & MIN \\
\hline 12 & iii. Adjacent-Micro-Local-Individual & Household expenditure on miscellaneous goods (optional needs) is the lowest. & MIN \\
\hline 13 & i. Adjacent-Micro-Local-Individual & $\begin{array}{l}\text { Household savings are the lowest. Smallest savings means that most of income is spent on basic needs. This is } \\
\text { the major driver of economic emigration. }\end{array}$ & MIN \\
\hline 14 & i. Adjacent-Micro-Local-Individual & $\begin{array}{c}\text { Single person income is the smallest. Smallest net income means that less money for optional expenditures and } \\
\text { savings. }\end{array}$ & MIN \\
\hline 15 & i. Adjacent-Micro-Local-Individual & $\begin{array}{c}\text { Family without children income is the smallest. Smallest net income means that less money for optional } \\
\text { expenditures and savings. }\end{array}$ & MIN \\
\hline 16 & i. Adjacent-Micro-Local-Individual & $\begin{array}{c}\text { Family with children income is the smallest. Smallest net income means that less money for optional } \\
\text { expenditures and savings. }\end{array}$ & MIN \\
\hline 17 & v. Neighboring-Mezo-National-External & $\begin{array}{l}\text { Household cost overburden rate is highest. Means that less money households can allocate for optional } \\
\text { expenditures and savings. }\end{array}$ & MAX \\
\hline 18 & v. Neighboring-Mezo-National-External & $\begin{array}{l}\text { Tenant ratio is the highest. Means competition for the housing is higher. It also means that less money } \\
\text { households can allocate for optional expenditures and savings. }\end{array}$ & MAX \\
\hline 19 & v. Neighboring-Mezo-National-External & $\begin{array}{l}\text { Homeowner ratio is the smallest. Means competition for the housing is smaller. It also means that more money } \\
\text { households can allocate for optional expenditures and savings. }\end{array}$ & MIN \\
\hline 20 & iv. Neighboring-Mezo-National-External & $\begin{array}{l}\text { Unemployment rate is the highest. Means that competition for workplaces is high. It also means that household } \\
\text { receive less income and have to allocate larger share of income for basic needs. }\end{array}$ & MAX \\
\hline 21 & iv. Neighboring-Mezo-National-External & $\begin{array}{l}\text { GDP is lowest. Low GDP show low country economic performance. It means that more money households } \\
\text { have to spend on basic needs. }\end{array}$ & MIN \\
\hline 22 & iv. Neighboring-Mezo-National-External & The low work intensity is the highest. It also means lower income for the households. & MAX \\
\hline 23 & iv. Neighboring-Mezo-National-External & $\begin{array}{l}\text { The highest number of population within the income poverty. It means that largest share of household income } \\
\text { is allocated only for the basic needs. }\end{array}$ & MAX \\
\hline 24 & vi. Distant-Macro-International-External & $\begin{array}{l}\text { The remittance inflows are highest. It also shows that economic and employment situation in the country is } \\
\text { tough because incoming remittances are used to support basic local household needs. }\end{array}$ & MAX \\
\hline 25 & vi. Distant-Macro-International-External & $\begin{array}{l}\text { The remittance outflows are lowest. It also shows that economic and employment situation in the country is } \\
\text { tough because the low outgoing remittances show that there is no possibility to earn decent savings. }\end{array}$ & MIN \\
\hline 26 & vi. Distant-Macro-International-External & The emigration is the highest. It shows that most of household income share are allocated for the basic needs. & MAX \\
\hline 27 & vi. Distant-Macro-International-External & $\begin{array}{l}\text { The immigration is the lowest. It shows that economic situation in country is tough and immigrants (especially } \\
\text { economic ones) cannot earn decent income and savings. }\end{array}$ & MIN \\
\hline 28 & vi. Distant-Macro-International-External & $\begin{array}{l}\text { The export is the lowest. No production, no export of goods, no import of money. It also means that households } \\
\text { in such country have to allocate more money for basic needs because of lower income. }\end{array}$ & MIN \\
\hline 29 & vi. Distant-Macro-International-External & $\begin{array}{l}\text { The import is the highest. No production, so import of goods and export of money. It also means that } \\
\text { households in such country have to allocate more money for basic needs because of lower income. }\end{array}$ & MAX \\
\hline
\end{tabular}


Table A3. Calculated importance $\left(q_{i}\right)$ of each criteria for 2008-2017.

\begin{tabular}{|c|c|c|c|c|c|c|c|c|c|c|c|}
\hline \multirow{2}{*}{$\begin{array}{l}\text { Criterion No. } \\
\text { (Table A1) }\end{array}$} & \multicolumn{10}{|c|}{ Year } & \multirow{2}{*}{$\begin{array}{l}\text { Objective Function } \\
\text { Applied }^{1}\end{array}$} \\
\hline & 2008 & 2009 & 2010 & 2011 & 2012 & 2013 & 2014 & 2015 & 2016 & 2017 & \\
\hline 1 & 0.034 & 0.034 & 0.034 & 0.034 & 0.034 & 0.034 & 0.034 & 0.034 & 0.034 & 0.034 & MAX \\
\hline 2 & 0.034 & 0.034 & 0.034 & 0.034 & 0.034 & 0.034 & 0.034 & 0.034 & 0.034 & 0.034 & MIN \\
\hline 3 & 0.034 & 0.034 & 0.034 & 0.034 & 0.034 & 0.034 & 0.034 & 0.034 & 0.034 & 0.034 & MIN \\
\hline 4 & 0.034 & 0.034 & 0.034 & 0.034 & 0.034 & 0.034 & 0.034 & 0.034 & 0.034 & 0.034 & MAX \\
\hline 5 & 0.034 & 0.034 & 0.034 & 0.034 & 0.034 & 0.034 & 0.034 & 0.034 & 0.034 & 0.034 & MIN \\
\hline 6 & 0.035 & 0.035 & 0.034 & 0.035 & 0.034 & 0.034 & 0.034 & 0.034 & 0.034 & 0.034 & MIN \\
\hline 7 & 0.034 & 0.034 & 0.034 & 0.034 & 0.034 & 0.034 & 0.034 & 0.034 & 0.034 & 0.034 & MAX \\
\hline 8 & 0.034 & 0.034 & 0.034 & 0.034 & 0.034 & 0.034 & 0.034 & 0.034 & 0.034 & 0.034 & MIN \\
\hline 9 & 0.034 & 0.034 & 0.034 & 0.034 & 0.034 & 0.034 & 0.034 & 0.034 & 0.034 & 0.034 & MIN \\
\hline 10 & 0.035 & 0.035 & 0.035 & 0.035 & 0.035 & 0.035 & 0.035 & 0.035 & 0.035 & 0.035 & MIN \\
\hline 11 & 0.035 & 0.034 & 0.035 & 0.035 & 0.035 & 0.035 & 0.035 & 0.034 & 0.035 & 0.035 & MIN \\
\hline 12 & 0.035 & 0.035 & 0.034 & 0.034 & 0.034 & 0.034 & 0.034 & 0.035 & 0.035 & 0.035 & MIN \\
\hline 13 & 0.036 & 0.036 & 0.036 & 0.036 & 0.036 & 0.036 & 0.036 & 0.036 & 0.036 & 0.036 & MIN \\
\hline 14 & 0.035 & 0.035 & 0.035 & 0.035 & 0.035 & 0.035 & 0.035 & 0.035 & 0.035 & 0.035 & MIN \\
\hline 15 & 0.035 & 0.035 & 0.035 & 0.035 & 0.035 & 0.035 & 0.035 & 0.035 & 0.035 & 0.035 & MIN \\
\hline 16 & 0.035 & 0.035 & 0.035 & 0.035 & 0.035 & 0.035 & 0.035 & 0.035 & 0.035 & 0.035 & MIN \\
\hline 17 & 0.034 & 0.035 & 0.034 & 0.035 & 0.035 & 0.035 & 0.035 & 0.035 & 0.035 & 0.035 & MAX \\
\hline 18 & 0.034 & 0.034 & 0.034 & 0.034 & 0.034 & 0.034 & 0.034 & 0.034 & 0.034 & 0.034 & MAX \\
\hline 19 & 0.034 & 0.034 & 0.034 & 0.034 & 0.034 & 0.034 & 0.034 & 0.034 & 0.034 & 0.034 & MIN \\
\hline 20 & 0.034 & 0.034 & 0.034 & 0.034 & 0.035 & 0.035 & 0.035 & 0.035 & 0.035 & 0.035 & MAX \\
\hline 21 & 0.035 & 0.035 & 0.035 & 0.035 & 0.035 & 0.035 & 0.035 & 0.035 & 0.035 & 0.035 & MIN \\
\hline 22 & 0.034 & 0.034 & 0.034 & 0.035 & 0.034 & 0.034 & 0.034 & 0.034 & 0.034 & 0.034 & MAX \\
\hline 23 & 0.034 & 0.034 & 0.034 & 0.034 & 0.034 & 0.034 & 0.034 & 0.034 & 0.034 & 0.034 & MAX \\
\hline 24 & 0.035 & 0.035 & 0.035 & 0.035 & 0.035 & 0.035 & 0.035 & 0.035 & 0.035 & 0.035 & MAX \\
\hline 25 & 0.035 & 0.035 & 0.035 & 0.035 & 0.035 & 0.035 & 0.035 & 0.035 & 0.035 & 0.035 & MIN \\
\hline 26 & 0.035 & 0.035 & 0.035 & 0.035 & 0.035 & 0.035 & 0.035 & 0.035 & 0.035 & 0.035 & MAX \\
\hline 27 & 0.036 & 0.036 & 0.036 & 0.036 & 0.035 & 0.035 & 0.035 & 0.035 & 0.035 & 0.035 & MIN \\
\hline 28 & 0.034 & 0.034 & 0.034 & 0.034 & 0.034 & 0.034 & 0.034 & 0.034 & 0.034 & 0.034 & MIN \\
\hline 29 & 0.035 & 0.035 & 0.035 & 0.035 & 0.035 & 0.035 & 0.035 & 0.035 & 0.035 & 0.035 & MAX \\
\hline
\end{tabular}

${ }^{1}$ Kendall's concordance coefficient $W=0.001$ in all cases.

Table A4. SAW results and compound annual growth rates (CAGR) (2008-2017).

\begin{tabular}{|c|c|c|c|c|c|c|c|c|c|c|c|}
\hline \multirow{2}{*}{ MS } & \multicolumn{10}{|c|}{ Year } & \multirow{2}{*}{ CAGR } \\
\hline & 2008 & 2009 & 2010 & 2011 & 2012 & 2013 & 2014 & 2015 & 2016 & 2017 & \\
\hline Belgium & 0.455 & 0.428 & 0.410 & 0.415 & 0.410 & 0.410 & 0.411 & 0.414 & 0.423 & 0.426 & -0.725 \\
\hline Bulgaria & 0.563 & 0.535 & 0.562 & 0.569 & 0.550 & 0.544 & 0.543 & 0.548 & 0.552 & 0.550 & -0.256 \\
\hline Czechia & 0.409 & 0.398 & 0.406 & 0.404 & 0.409 & 0.422 & 0.428 & 0.430 & 0.427 & 0.428 & 0.521 \\
\hline Denmark & 0.419 & 0.421 & 0.430 & 0.419 & 0.413 & 0.421 & 0.422 & 0.422 & 0.430 & 0.437 & 0.466 \\
\hline Germany & 0.452 & 0.425 & 0.422 & 0.419 & 0.412 & 0.414 & 0.415 & 0.416 & 0.428 & 0.431 & -0.532 \\
\hline Estonia & 0.404 & 0.414 & 0.437 & 0.438 & 0.440 & 0.435 & 0.435 & 0.429 & 0.431 & 0.432 & 0.770 \\
\hline Ireland & 0.381 & 0.383 & 0.399 & 0.418 & 0.411 & 0.401 & 0.402 & 0.396 & 0.404 & 0.402 & 0.590 \\
\hline Greece & 0.438 & 0.414 & 0.429 & 0.468 & 0.497 & 0.503 & 0.508 & 0.513 & 0.521 & 0.524 & 2.004 \\
\hline Spain & 0.424 & 0.416 & 0.437 & 0.449 & 0.458 & 0.473 & 0.475 & 0.473 & 0.471 & 0.473 & 1.231 \\
\hline France & 0.428 & 0.414 & 0.424 & 0.423 & 0.425 & 0.428 & 0.428 & 0.433 & 0.440 & 0.447 & 0.464 \\
\hline Croatia & 0.445 & 0.424 & 0.434 & 0.424 & 0.438 & 0.441 & 0.449 & 0.452 & 0.452 & 0.457 & 0.302 \\
\hline Italy & 0.402 & 0.383 & 0.393 & 0.391 & 0.396 & 0.406 & 0.412 & 0.413 & 0.426 & 0.430 & 0.748 \\
\hline Cyprus & 0.370 & 0.352 & 0.364 & 0.360 & 0.394 & 0.402 & 0.402 & 0.398 & 0.398 & 0.403 & 0.979 \\
\hline Latvia & 0.481 & 0.495 & 0.505 & 0.506 & 0.493 & 0.478 & 0.467 & 0.465 & 0.469 & 0.470 & -0.268 \\
\hline Lithuania & 0.479 & 0.482 & 0.525 & 0.518 & 0.486 & 0.485 & 0.477 & 0.488 & 0.490 & 0.490 & 0.275 \\
\hline Luxembourg & 0.444 & 0.430 & 0.426 & 0.430 & 0.428 & 0.429 & 0.433 & 0.435 & 0.441 & 0.453 & 0.220 \\
\hline Hungary & 0.451 & 0.428 & 0.434 & 0.439 & 0.446 & 0.450 & 0.442 & 0.433 & 0.432 & 0.431 & -0.501 \\
\hline Malta & 0.381 & 0.376 & 0.375 & 0.373 & 0.362 & 0.368 & 0.365 & 0.368 & 0.373 & 0.369 & -0.372 \\
\hline Netherlands & 0.386 & 0.377 & 0.385 & 0.386 & 0.381 & 0.386 & 0.388 & 0.392 & 0.391 & 0.394 & 0.219 \\
\hline Austria & 0.390 & 0.379 & 0.385 & 0.393 & 0.385 & 0.387 & 0.386 & 0.387 & 0.395 & 0.402 & 0.358 \\
\hline Poland & 0.482 & 0.464 & 0.455 & 0.451 & 0.442 & 0.442 & 0.440 & 0.445 & 0.447 & 0.437 & -1.095 \\
\hline Portugal & 0.417 & 0.393 & 0.405 & 0.410 & 0.440 & 0.447 & 0.453 & 0.453 & 0.450 & 0.448 & 0.790 \\
\hline Romania & 0.658 & 0.633 & 0.600 & 0.607 & 0.612 & 0.580 & 0.582 & 0.581 & 0.585 & 0.578 & -1.421 \\
\hline Slovenia & 0.377 & 0.369 & 0.377 & 0.379 & 0.383 & 0.395 & 0.397 & 0.403 & 0.408 & 0.410 & 0.939 \\
\hline
\end{tabular}


Table A4. Cont.

\begin{tabular}{cccccccccccc}
\hline \multirow{2}{*}{ MS } & \multicolumn{10}{c}{ Year } & \multirow{2}{*}{ CAGR } \\
\cline { 2 - 16 } & $\mathbf{2 0 0 8}$ & $\mathbf{2 0 0 9}$ & $\mathbf{2 0 1 0}$ & $\mathbf{2 0 1 1}$ & $\mathbf{2 0 1 2}$ & $\mathbf{2 0 1 3}$ & $\mathbf{2 0 1 4}$ & $\mathbf{2 0 1 5}$ & $\mathbf{2 0 1 6}$ & $\mathbf{2 0 1 7}$ & \\
\hline Slovakia & 0.419 & 0.403 & 0.418 & 0.418 & 0.439 & 0.446 & 0.445 & 0.447 & 0.450 & 0.451 & 0.824 \\
Finland & 0.386 & 0.377 & 0.384 & 0.385 & 0.387 & 0.393 & 0.401 & 0.409 & 0.417 & 0.422 & 0.987 \\
Sweden & 0.425 & 0.417 & 0.419 & 0.421 & 0.411 & 0.416 & 0.414 & 0.418 & 0.424 & 0.429 & 0.112 \\
United Kingdom & 0.446 & 0.430 & 0.433 & 0.427 & 0.417 & 0.421 & 0.423 & 0.423 & 0.432 & 0.433 & -0.323 \\
\hline
\end{tabular}

Table A5. TOPSIS results and CAGR (2008-2017).

\begin{tabular}{|c|c|c|c|c|c|c|c|c|c|c|c|}
\hline \multirow{2}{*}{ MS } & \multicolumn{10}{|c|}{ Year } & \multirow{2}{*}{ CAGR } \\
\hline & 2008 & 2009 & 2010 & 2011 & 2012 & 2013 & 2014 & 2015 & 2016 & 2017 & \\
\hline Belgium & 0.558 & 0.551 & 0.548 & 0.559 & 0.552 & 0.539 & 0.535 & 0.536 & 0.541 & 0.548 & -0.216 \\
\hline Bulgaria & 0.588 & 0.567 & 0.570 & 0.582 & 0.581 & 0.569 & 0.561 & 0.568 & 0.572 & 0.578 & -0.206 \\
\hline Czechia & 0.557 & 0.545 & 0.554 & 0.562 & 0.550 & 0.538 & 0.533 & 0.536 & 0.534 & 0.541 & -0.327 \\
\hline Denmark & 0.535 & 0.530 & 0.532 & 0.536 & 0.529 & 0.517 & 0.515 & 0.510 & 0.512 & 0.522 & -0.275 \\
\hline Germany & 0.552 & 0.538 & 0.534 & 0.539 & 0.527 & 0.513 & 0.506 & 0.502 & 0.511 & 0.517 & -0.718 \\
\hline Estonia & 0.567 & 0.555 & 0.571 & 0.581 & 0.569 & 0.553 & 0.542 & 0.540 & 0.541 & 0.541 & -0.514 \\
\hline Ireland & 0.494 & 0.490 & 0.499 & 0.519 & 0.504 & 0.491 & 0.485 & 0.475 & 0.474 & 0.477 & -0.409 \\
\hline Greece & 0.557 & 0.541 & 0.544 & 0.575 & 0.589 & 0.586 & 0.591 & 0.598 & 0.593 & 0.599 & 0.822 \\
\hline Spain & 0.539 & 0.537 & 0.546 & 0.556 & 0.556 & 0.549 & 0.542 & 0.542 & 0.540 & 0.546 & 0.140 \\
\hline France & 0.542 & 0.531 & 0.538 & 0.544 & 0.531 & 0.519 & 0.515 & 0.521 & 0.522 & 0.529 & -0.265 \\
\hline Croatia & 0.585 & 0.572 & 0.572 & 0.575 & 0.564 & 0.553 & 0.549 & 0.555 & 0.555 & 0.563 & -0.413 \\
\hline Italy & 0.531 & 0.520 & 0.526 & 0.536 & 0.530 & 0.519 & 0.515 & 0.520 & 0.525 & 0.531 & 0.012 \\
\hline Cyprus & 0.527 & 0.480 & 0.502 & 0.501 & 0.529 & 0.539 & 0.535 & 0.519 & 0.512 & 0.514 & -0.274 \\
\hline Latvia & 0.622 & 0.607 & 0.621 & 0.628 & 0.613 & 0.591 & 0.577 & 0.577 & 0.571 & 0.576 & -0.853 \\
\hline Lithuania & 0.606 & 0.593 & 0.631 & 0.630 & 0.599 & 0.588 & 0.577 & 0.578 & 0.576 & 0.583 & -0.426 \\
\hline Luxembourg & 0.413 & 0.417 & 0.407 & 0.403 & 0.400 & 0.396 & 0.397 & 0.404 & 0.411 & 0.413 & -0.025 \\
\hline Hungary & 0.569 & 0.553 & 0.558 & 0.572 & 0.568 & 0.553 & 0.541 & 0.537 & 0.535 & 0.543 & -0.519 \\
\hline Malta & 0.541 & 0.514 & 0.527 & 0.531 & 0.503 & 0.487 & 0.475 & 0.480 & 0.482 & 0.474 & -1.463 \\
\hline Netherlands & 0.515 & 0.505 & 0.513 & 0.519 & 0.510 & 0.502 & 0.496 & 0.498 & 0.488 & 0.494 & -0.459 \\
\hline Austria & 0.529 & 0.518 & 0.522 & 0.528 & 0.511 & 0.499 & 0.492 & 0.491 & 0.496 & 0.507 & -0.462 \\
\hline Poland & 0.587 & 0.572 & 0.572 & 0.582 & 0.569 & 0.554 & 0.547 & 0.545 & 0.541 & 0.543 & -0.855 \\
\hline Portugal & 0.565 & 0.543 & 0.550 & 0.565 & 0.561 & 0.552 & 0.548 & 0.550 & 0.546 & 0.549 & -0.324 \\
\hline Romania & 0.609 & 0.584 & 0.573 & 0.571 & 0.569 & 0.561 & 0.557 & 0.559 & 0.558 & 0.565 & -0.842 \\
\hline Slovenia & 0.533 & 0.524 & 0.543 & 0.552 & 0.540 & 0.529 & 0.525 & 0.527 & 0.527 & 0.532 & -0.012 \\
\hline Slovakia & 0.568 & 0.558 & 0.560 & 0.570 & 0.559 & 0.545 & 0.541 & 0.543 & 0.541 & 0.546 & -0.428 \\
\hline Finland & 0.528 & 0.516 & 0.522 & 0.528 & 0.517 & 0.505 & 0.504 & 0.509 & 0.510 & 0.517 & -0.225 \\
\hline Sweden & 0.541 & 0.531 & 0.528 & 0.533 & 0.515 & 0.501 & 0.495 & 0.500 & 0.494 & 0.503 & -0.787 \\
\hline United Kingdom & 0.537 & 0.523 & 0.521 & 0.531 & 0.510 & 0.500 & 0.495 & 0.492 & 0.498 & 0.507 & -0.639 \\
\hline
\end{tabular}


Table A6. CAGR (2008-2017) of each indicator, by EU MS. Pearson correlation coefficients R1 and R2 show relationship between CAGR of each criterion with CAGR of SAW (Table A4) and TOPSIS (Table A5), by MS.

\begin{tabular}{|c|c|c|c|c|c|c|c|c|c|c|c|c|c|c|c|c|c|c|c|c|c|c|c|c|c|c|c|c|c|}
\hline \multirow{2}{*}{ MS } & \multicolumn{29}{|c|}{ Criterion Number (Table A1) } \\
\hline & 1 & 2 & 3 & 4 & 5 & 6 & 7 & 8 & 9 & 10 & 11 & 12 & 13 & 14 & 15 & 16 & 17 & 18 & 19 & 20 & 21 & 22 & 23 & 24 & 25 & 26 & 27 & 28 & 29 \\
\hline Belgium & 0.518 & 0.557 & 0.464 & 0.723 & 0.000 & 1.048 & -1.223 & -0.962 & -1.389 & 0.000 & 1.317 & -0.983 & -4.414 & 1.672 & 1.688 & 1.620 & -3.466 & -0.735 & 0.235 & 0.371 & 0.521 & 1.603 & 0.876 & -0.656 & 0.497 & 3.790 & -1.582 & 0.191 & 0.097 \\
\hline B & -0.671 & 249 & .341 & 1.332 & -2.873 & 4.889 & -1.413 & 300 & -0.141 & 3.602 & 2.347 & 10 & 0.0 & 6.342 & 6.342 & & 3.5 & 3.026 & -0.461 & 1.663 & 2.305 & 3.5 & 0.998 & 2.204 & 2.959 & 14.423 & 13.368 & 2.798 & -1.518 \\
\hline Czechia & 1.231 & 1.178 & .296 & 0.044 & -0.805 & -1.300 & 0.336 & 205 & -1.381 & -3.670 & 1.896 & .739 & -1.986 & 2.442 & 2.442 & 128 & -4.200 & -0.940 & 0.254 & -4.405 & 1.214 & -2.948 & 0.123 & 3.369 & -2.739 & -7.031 & -8.086 & 2.611 & 1.872 \\
\hline Denmark & 95 & -0.616 & -0.782 & 0.897 & -0.411 & 0.405 & -0.633 & -0.541 & -0.188 & 1.495 & 0.955 & -1.258 & 11.441 & 1.550 & 1.550 & 633 & -0.945 & 0.961 & -0.565 & 6.800 & 0.397 & 1.822 & 0.553 & 2.265 & -3.495 & 3.815 & 1.455 & 0.183 & -0.583 \\
\hline Germany & -0.103 & -0.341 & -0.903 & -0.677 & 0.526 & 0.893 & 0.332 & -2.162 & 0.518 & 1.317 & 0.859 & 0.359 & 0.213 & 2.405 & 2.405 & 373 & 0.000 & 0.278 & -0.257 & -7.710 & 1.023 & -3.238 & 0.641 & 4.787 & 4.176 & -3.045 & 3.301 & 0.882 & 0.744 \\
\hline & 0112 & 0.720 & 0.170 & 0.434 & -1.215 & 1.495 & -1.088 & -4.546 & 0.268 & -5.088 & 2.716 & -1.041 & 4.914 & 5.234 & 5.234 & 355 & 3.248 & 3.083 & -0.582 & 1.372 & 1.490 & 1.007 & 0.827 & 382 & 5.119 & 12.356 & 19.264 & 1.544 & 0.266 \\
\hline & & -1.393 & .331 & & -3.634 & & 0.433 & -2.362 & -1.565 & 0.455 & 2.684 & & & & & & & & & & & & & 1.057 & -6.282 & -1.099 & -1.341 & 4.125 & \\
\hline & & 1001 & $x$ & & $\begin{array}{l}-7.038 \\
\end{array}$ & & -1.300 & 2.255 & -0.239 & -1.473 & & & & & & & & & & & & & & & & & & & \\
\hline & & & -1 & & -1 . & 1. & 0.2 & & & 2.334 & -0.294 & -0 & & 0.8 & 0 & 0 & & & 60 & & 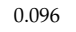 & & & & & & & & 31 \\
\hline & & & & & & & & & & & & & & & & & & & & & & & & & & & & & \\
\hline & & & & & & & & & & & & & & & & & & & & & & & & & & & & & \\
\hline & & & & & & & & & & & & & & & & & & & & & & & & & & & & & \\
\hline & & & & & -1 & & & & & & & & & & & & & & & & & & & & & & & & \\
\hline & & & & & & & & 25 & & & & & & & & & & & & & & & & & & & & & \\
\hline & & 358 & & & & & & & & & & & & & & & & & & & & & & & & & & & \\
\hline & & 98 & & & & & & & & & & & & & & & & & & & & & & & & & & & \\
\hline & & & & & & & 2 & & & & & & & & & & & & & -6.974 & & & & & -6.034 & $=17$ & & & 10 \\
\hline & & & & & & & & & & & & & & & & & & & & -4 & & & & & & & & & \\
\hline & & & & & & & & & & & & & & & & & & & & 4. & & & & & -1.675 & & & & \\
\hline & & & & & & & & & $0 . c$ & & & & & & & & & & & & & & & & 5.2 & & & & \\
\hline & & - & & & & & & -3 & & & 2.8 & & & & & & & & & -3.781 & & & & & 16.633 & 24.672 & & 70 & \\
\hline & & 5 & & & & & & -2 & -1.809 & 0.0 & & & & 0. & & & -1 & & & 0.7 & & & -0.121 & & 0.052 & & & 11 & \\
\hline & & & & & & & -3.755 & 71 & 2.732 & & & 0.5 & & 6. & & & -4.772 & & & -1.079 & & & & & & 916 & & 243 & \\
\hline & - & 0 & & & & & & & & 0.000 & & & & & & & & & & 5.903 & & & & & & & 83 & & \\
\hline & 0 & 1.728 & -1.506 & -0.787 & $\begin{array}{r}-0.872 \\
\end{array}$ & 3. & & -1.300 & 0.8 & 1 & -1.238 & & & & & & & -6 & & -1.677 & & & & & 8.585 & & 2.299 & 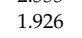 & \\
\hline & & -0.700 & -1.473 & 2.110 & -1.531 & & & -0.885 & 1 & & 0.0 & & & & & & & & & 4.2 & & & & & & & & & \\
\hline & 0.1 & 22 & 0 & -0.386 & 0 & 0 & 0.0 & 1.137 & - & 0. & 1.4 & & 2.42 & & & 3.161 & -1.919 & -0.570 & 0.200 & 2.676 & 0.9 & 2.5 & 1.100 & -4.426 & 2.728 & -0.858 & 004 & -1.134 & .703 \\
\hline Kingdom & -0.281 & -1.300 & 0.437 & -0.042 & 0.495 & 3.451 & -0.406 & -1.228 & 0.305 & 5.361 & 0.234 & 0.832 & -5.363 & 2.059 & 2.059 & 2.012 & -2.993 & 1.958 & -0.755 & -2.174 & 0.534 & -0.325 & -1.053 & -4.116 & -2.301 & -2.623 & 0.227 & 1.327 & 0.920 \\
\hline & & & & & & & & & & & & & & & & & & & & & & & & & & & & & \\
\hline & & & & & & & & & & & & & & & & & & & & & & & & & & & & & \\
\hline
\end{tabular}




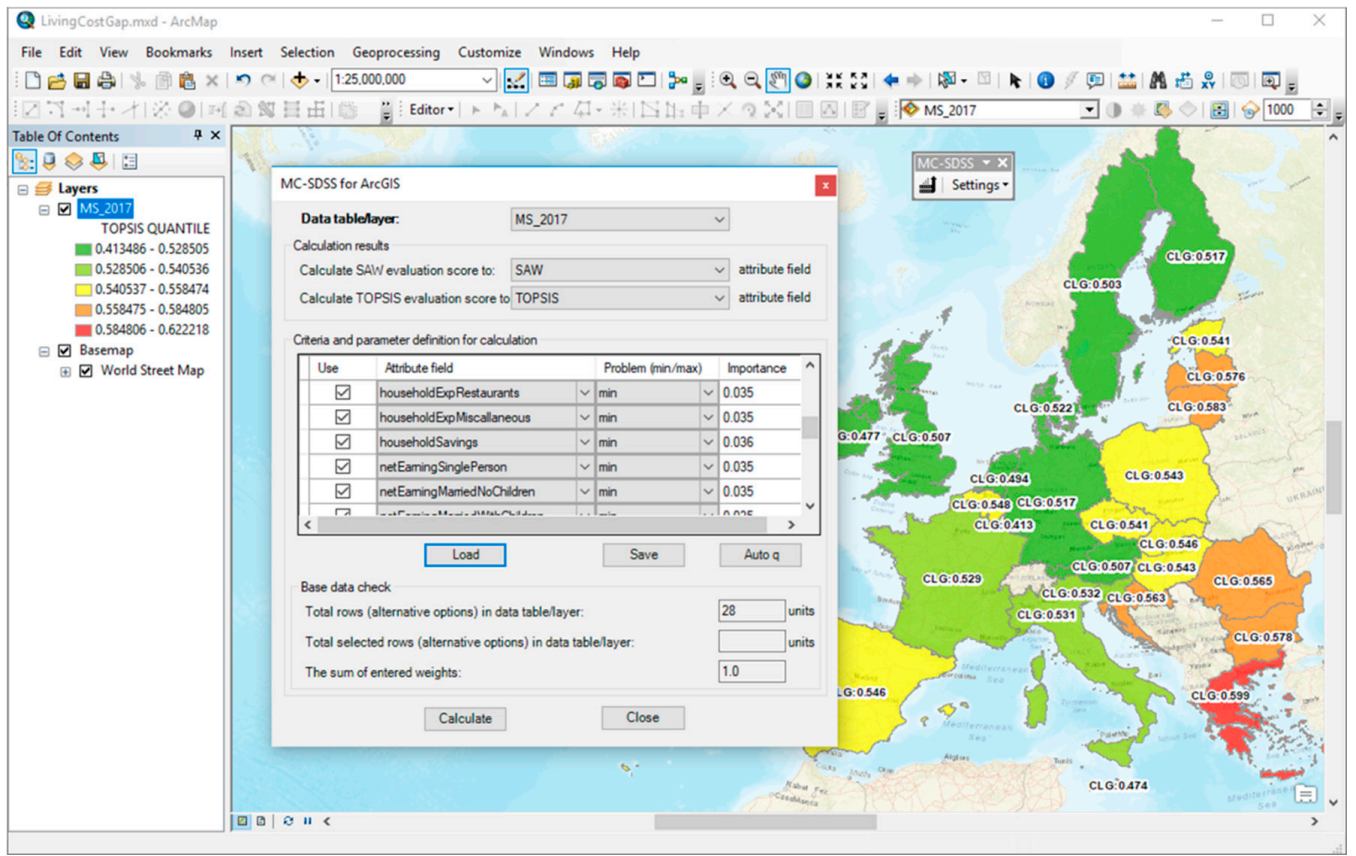

Figure A1. Interface of multiple criteria spatial decision support system (MC-SDSS extension for ESRI inc. ArcGIS Desktop [55]) within ArcMap environment.

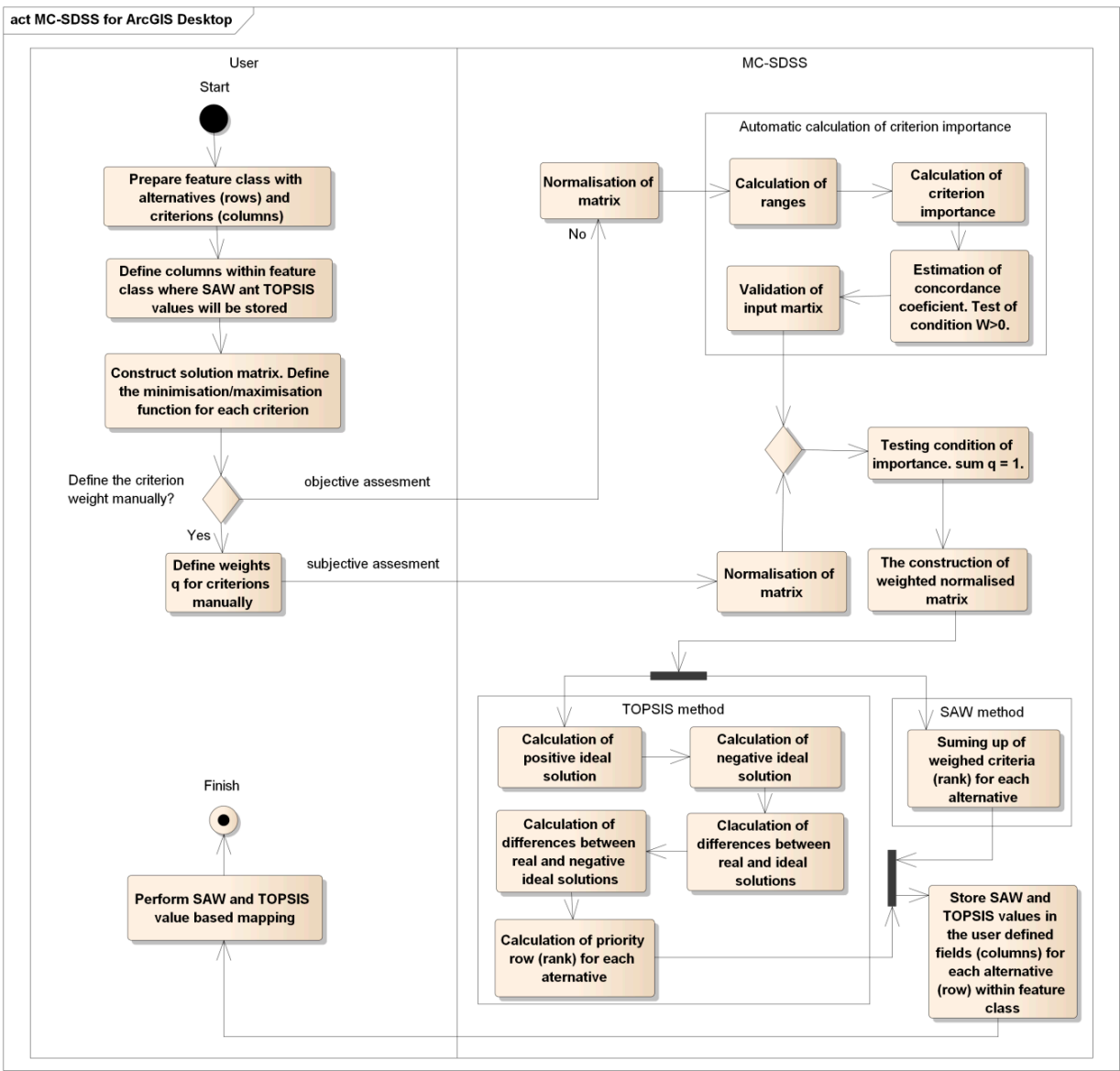

Figure A2. Unified Modelling Language [57] based activity diagram describing workflow processes that implement objective and subjective criteria weighting, criteria normalization, data concordance, and MCDM (SAW and TOPSIS) techniques within GIS (ArcGIS Desktop) environment (MC-SDSS extension for ESRI inc. ArcGIS Desktop [55]). 


\section{References}

1. Alesina, A.; Di Tella, R.; MacCulloch, R. Inequality and happiness: Are Europeans and Americans different? J. Public Econ. 2004, 88, 2009-2042. [CrossRef]

2. Bettencourt, L.M.A.; Lobo, J.; Helbing, D.; Kuhnert, C.; West, G.B. Growth, innovation, scaling, and the pace of life in cities. Proc. Natl. Acad. Sci. USA 2007, 104, 7301-7306. [CrossRef]

3. Charron, N.; Dijkstra, L.; Lapuente, V. Erratum to: Mapping the Regional Divide in Europe: A Measure for Assessing Quality of Government in 206 European Regions. Soc. Indic. Res. 2015, 124, 1059. [CrossRef]

4. Glaeser, E.L.; Resseger, M.; Tobio, K. Inequality in cities. J. Reg. Sci. 2009, 49, 617-646. [CrossRef]

5. Persson, T.; Tabellini, G. Is Inequality Harmful for Growth? Theory and Evidence. Natl. Bur. Econ. Res. 1991. [CrossRef]

6. Reardon, S.F.; O'Sullivan, D. Measures of Spatial Segregation. Sociol. Methodol. 2004, 34, 121-162. [CrossRef]

7. Norris, M.; Winston, N. Home-ownership, housing regimes and income inequalities in Western Europe. Int. J. Soc. Welf. 2012, 21, 127-138. [CrossRef]

8. Vojnovic, I. Urban sustainability: Research, politics, policy and practice. Cities 2014, 41, S30-S44. [CrossRef]

9. Dijkstra, L. My Region, My Europe, Our Future. Seventh Report on Economic, Social and Territorial Cohesion; Publications Office of the European Union: Luxembourg, 2017; ISBN 978-92-79-71834-2.

10. Scholliers, P.; Schwarz, L.D. Experiencing Wages: Social and Cultural Aspects of Wage Forms in Europe since 1500; Berghahn Books: New York, NY, USA, 2003; Volume 4, ISBN 1-57181-546-5.

11. Dijkstra, L.; Garcilazo, E.; McCann, P. The Economic Performance of European Cities and City Regions: Myths and Realities. Eur. Plan. Stud. 2013, 21, 334-354. [CrossRef]

12. Quigley, J.M.; Raphael, S. Is Housing Unaffordable? Why Isn't It More Affordable? J. Econ. Perspect. 2004, 18, 191-214. [CrossRef]

13. Mimura, Y. Housing Cost Burden, Poverty Status, and Economic Hardship among Low-income Families. J. Fam. Econ. Issues 2008, 29, 152-165. [CrossRef]

14. Saiz, A. Immigration and housing rents in American cities. J. Urban Econ. 2007, 61, 345-371. [CrossRef]

15. McConnell, E.D.; Akresh, I.R. Housing Cost Burden and New Lawful Immigrants in the United States. Popul. Res. Policy Rev. 2010, 29, 143-171. [CrossRef]

16. Dohmen, T.J. Housing, mobility and unemployment. Reg. Sci. Urban Econ. 2005, 35, 305-325. [CrossRef]

17. Blanchard, O.; Katz, L.F. What We Know and Do Not Know About the Natural Rate of Unemployment. J. Econ. Perspect. 1997, 11, 51-72. [CrossRef]

18. Arundel, R.; Lennartz, C. Housing market dualization: Linking insider-outsider divides in employment and housing outcoms. Hous. Stud. 2019, 1-25. [CrossRef]

19. Moser, C.O.N. The asset vulnerability framework: Reassessing urban poverty reduction strategies. World Dev. 1998, 26, 1-19. [CrossRef]

20. Lustig, N. Economic crisis, adjustment and living standards in Mexico, 1982-1985. World Dev. 1990, 18, 1325-1342. [CrossRef]

21. Colombo, E.; Menna, L.; Tirelli, P. Informality and the labor market effects of financial crises. World Dev. 2019, 119, 1-22. [CrossRef]

22. Gilbert, A. Third World Cities: Housing, Infrastructure and Servicing. Urban Stud. 1992, 29, 435-460. [CrossRef]

23. Pratt, A.C.; Hutton, T.A. Reconceptualising the relationship between the creative economy and the city: Learning from the financial crisis. Cities 2013, 33, 86-95. [CrossRef]

24. Fowler, K.A.; Gladden, R.M.; Vagi, K.J.; Barnes, J.; Frazier, L. Increase in Suicides Associated With Home Eviction and Foreclosure During the US Housing Crisis: Findings From 16 National Violent Death Reporting System States, 2005-2010. Am. J. Public Health 2015, 105, 311-316. [CrossRef]

25. Zhang, F.; Zhang, C.; Hudson, J. Housing conditions and life satisfaction in urban China. Cities 2018, 81, 35-44. [CrossRef]

26. Li, J.; Liu, Z. Housing stress and mental health of migrant populations in urban China. Cities 2018, 81, 172-179. [CrossRef]

27. Stuckler, D.; Basu, S.; Suhrcke, M.; Coutts, A.; McKee, M. The public health effect of economic crises and alternative policy responses in Europe: An empirical analysis. Lancet 2009, 374, 315-323. [CrossRef] 
28. Chien, N.C.; Mistry, R.S. Geographic Variations in Cost of Living: Associations With Family and Child Well-Being. Child Dev. 2013, 84, 209-225. [CrossRef] [PubMed]

29. Haffner, M.E.A.; Boumeester, H.J.F.M. The Affordability of Housing in the Netherlands: An Increasing Income Gap Between Renting and Owning? Hous. Stud. 2010, 25, 799-820. [CrossRef]

30. Partridge, M.D.; Rickman, D.S.; Ali, K.; Olfert, M.R. Agglomeration spillovers and wage and housing cost gradients across the urban hierarchy. J. Int. Econ. 2009, 78, 126-140. [CrossRef]

31. Stolarick, K.; Currid-Halkett, E. Creativity and the crisis: The impact of creative workers on regional unemployment. Cities 2013, 33, 5-14. [CrossRef]

32. Rakodi, C. Poverty lines or household strategies? Habitat Int. 1995, 19, 407-426. [CrossRef]

33. Perpiña Castillo, C.; Kavalov, B.; Ribeiro Barranco, R.; Diogo, V.; Jacobs, C.; Batista, E.; Silva, F.; Baranzelli, C.; Lavalle, C. Territorial Facts and Trends in the EU Rural Areas within 2015-2030; Publications Office of the European Union: Luxembourg, 2018; ISBN 978-92-79-98121-0.

34. Haggblade, S.; Hazell, P.; Reardon, T. The Rural Non-farm Economy: Prospects for Growth and Poverty Reduction. World Dev. 2010, 38, 1429-1441. [CrossRef]

35. Hulme, D. Chronic Poverty and Development Policy: An Introduction. World Dev. 2003, 31, $399-402$. [CrossRef]

36. Engelman, R. Beyond Sustainababble. In State of the World 2013; Island Press/Center for Resource Economics: Washington, DC, USA, 2013; pp. 3-16.

37. Jankowski, P. Integrating geographical information systems and multiple criteria decision-making methods. Int. J. Geogr. Inf. Syst. 1995, 9, 251-273. [CrossRef]

38. Hwang, C.-L.; Yoon, K. Multiple Attribute Decision Making; Lecture Notes in Economics and Mathematical Systems; Springer: Berlin/Heidelberg, Germany, 1981; Volume 186, ISBN 978-3-540-10558-9.

39. Mardani, A.; Jusoh, A.; Zavadskas, E.K. Fuzzy multiple criteria decision-making techniques and applications-Two decades review from 1994 to 2014. Expert Syst. Appl. 2015, 42, 4126-4148. [CrossRef]

40. Malczewski, J. GIS-based multicriteria decision analysis: A survey of the literature. Int. J. Geogr. Inf. Sci. 2006, 20, 703-726. [CrossRef]

41. Directorate-General of the European Commission Eurostat (European Statistical Office) Household Expenditures 2008-2017. Available online: https://ec.europa.eu/eurostat/databrowser/view/tec00134/default/ table?lang=en (accessed on 16 September 2020).

42. Directorate-General of the European Commission Eurostat (European Statistical Office) Household Savings 2008-2017. Available online: https://ec.europa.eu/eurostat/databrowser/view/tec00131/default/table?lang= en $\% 0 \mathrm{~A}$ (accessed on 16 September 2020).

43. Directorate-General of the European Commission Eurostat (European Statistical Office) Net Earnings 2008-2017. Available online: https://appsso.eurostat.ec.europa.eu/nui/show.do?dataset=earn_nt_net\&lang= en\%0A (accessed on 16 September 2020).

44. Directorate-General of the European Commission Eurostat (European Statistical Office) Housing Cost Overburden Rate 2008-2017. Available online: https://ec.europa.eu/eurostat/databrowser/view/tespm140/ default/table?lang=en\%0A (accessed on 16 September 2020).

45. Directorate-General of the European Commission Eurostat (European Statistical Office) Housing Tenure Status 2008-2017. Available online: https://ec.europa.eu/eurostat/statistics-explained/index.php?title= Housing_statistics\#Type_of_dwelling\%0A (accessed on 16 September 2020).

46. Directorate-General of the European Commission Eurostat (European Statistical Office) Unemployment Rate 2008-2017. Available online: https:/ec.europa.eu/eurostat/databrowser/view/tipsun20/default/table?lang= en $\% 0 \mathrm{~A}$ (accessed on 16 September 2020).

47. Directorate-General of the European Commission Eurostat (European Statistical Office) Gross Domestic Product 2008-2017. Available online: https://appsso.eurostat.ec.europa.eu/nui/show.do?dataset=namq_10_ gdp\&lang=en (accessed on 16 September 2020).

48. Directorate-General of the European Commission Eurostat (European Statistical Office) Low work Intensity 2008-2017. Available online: https://ec.europa.eu/eurostat/databrowser/view/t2020_51/default/table?lang= en\%0A (accessed on 16 September 2020).

49. Directorate-General of the European Commission Eurostat (European Statistical Office) Income Poverty 2008-2017. Available online: https://ec.europa.eu/eurostat/databrowser/view/sdg_01_20/default/table?lang= en $\% 0 \mathrm{~A}$ (accessed on 16 September 2020). 
50. Directorate-General of the European Commission Eurostat (European Statistical Office) Emmigration 2008-2017. Available online: https:/ec.europa.eu/eurostat/databrowser/view/tps00177/default/table?lang= en $\% 0 \mathrm{~A}$ (accessed on 16 September 2020).

51. Directorate-General of the European Commission Eurostat (European Statistical Office) Immigration 2008-2017. Available online: https://ec.europa.eu/eurostat/databrowser/view/tps00176/default/table?lang= en $\% 0 \mathrm{~A}$ (accessed on 16 September 2020).

52. Directorate-General of the European Commission Eurostat (European Statistical Office) Exports of Goods and Services 2008-2017. Available online: https:/ec.europa.eu/eurostat/databrowser/view/tet00003/default/ table?lang=en \%0A (accessed on 16 September 2020).

53. Directorate-General of the European Commission Eurostat (European Statistical Office) Imports of Goods and Services 2008-2017. Available online: https:/ec.europa.eu/eurostat/databrowser/view/tet00004/default/ table?lang=en \%0A (accessed on 16 September 2020).

54. The World Bank Migration and Remittances Data 2008-2017. Available online: https://www.worldbank. org/en/topic/migrationremittancesdiasporaissues/brief/migration-remittances-data\%0A (accessed on 16 September 2020).

55. Kučas, A. Location prioritization by means of multicriteria spatial decision-support systems: A case study of forest fragmentation-based ranking of forest administrative areas. J. Environ. Eng. Landsc. Manag. 2010, 18, 312-320. [CrossRef]

56. Anson, M.J.P.; Fabozzi, F.J.; Jones, F.J. The Handbook of Traditional and Alternative Investment Vehicles: Investment Characteristics and Strategies; John Wiley \& Sons, Ltd.: Hoboken, NJ, USA, 2011; ISBN 978-0-470-60973-6.

57. ISO/IEC JTC 1/SC 7 Software and Systems Engineering. ISO/IEC 19501:2005. Information technology-Open Distributed Processing-Unified Modeling Language (UML) Version 1.4.2; International Organisation for Standartization: Geneva, Switzerland, 2005.

58. Keenan, P.B. Spatial Decision Support Systems. In Decision-Making Support Systems; IGI Global: Philadeplhia, PA, USA, 2003; pp. 28-39. [CrossRef]

59. Legendre, P. Species associations: The Kendall coefficient of concordance revisited. J. Agric. Biol. Environ. Stat. 2005, 10, 226-245. [CrossRef]

60. Wira Trise Putra, D.; Agustian Punggara, A. Comparison Analysis of Simple Additive Weighting (SAW) and Weigthed Product (WP) In Decision Support Systems. MATEC Web Conf. 2018, 215, 01003. [CrossRef]

61. Chen, T.-Y. Comparative analysis of SAW and TOPSIS based on interval-valued fuzzy sets: Discussions on score functions and weight constraints. Expert Syst. Appl. 2012, 39, 1848-1861. [CrossRef]

62. Zavadskas, E.K.; Turskis, Z.; Dejus, T.; Viteikiene, M. Sensitivity analysis of a simple additive weight method. Int. J. Manag. Decis. Mak. 2007, 8, 555. [CrossRef]

63. Zanakis, S.H.; Solomon, A.; Wishart, N.; Dublish, S. Multi-attribute decision making: A simulation comparison of select methods. Eur. J. Oper. Res. 1998, 107, 507-529. [CrossRef]

64. Jacobs, C.; Pinto Nunes Nogueira Diogo, V.; Perpiña Castillo, C.; Baranzelli, C.; Batista, E.; Silva, F.; Rosina, K.; Kavalov, B.; Lavalle, C. The LUISA Territorial Reference Scenario 2017; Publications Office of the European Union: Luxembourg, 2017; ISBN 978-92-79-73866-1.

65. European Commission DG JRC European Commision Urban Data Platform. Available online: https: //urban.jrc.ec.europa.eu/\#/en (accessed on 31 March 2020).

66. Rocher, S.; Stierle, M.H. Household Saving Rates in the EU. Why Do They Differ So Much? Publications Office of the European Union: Luxembourg, 2015; ISBN 978-92-79-48666-1.

67. Atkinson, A.B. On the measurement of inequality. J. Econ. Theory 1970, 2, 244-263. [CrossRef]

68. Gini, C. Measurement of Inequality of Incomes. Econ. J. 1921, 31, 124. [CrossRef]

69. Alkire, S.; Sumner, A. Multidimensional Poverty and the Post-2015 MDGs. Development 2013, 56, 46-51. [CrossRef]

70. Lazim, M.A.; Abu Osman, M.T. A New Malaysian Quality of Life Index Based on Fuzzy Sets and Hierarchical Needs. Soc. Indic. Res. 2009, 94, 499-508. [CrossRef]

71. Sharpe, A. A Survey of Indicators of Economic and Social Well-Being; Centre for the Study of Living Standards: Ottawa, ON, Canada, 1999.

72. Akoglu, H. User's guide to correlation coefficients. Turkish J. Emerg. Med. 2018, 18, 91-93. [CrossRef] [PubMed] 
73. Pelgrin, F.; de Serres, A. The Decline in Private Saving Rates in the 1990s in OECD Countries: How Much Can Be Explained by Non-wealth Determinants? OECD Econ. Stud. 2003, 2003, 117-153. [CrossRef]

74. Dynan, K.E.; Skinner, J.; Zeldes, S.P. Do the Rich Save More? J. Polit. Econ. 2004, 112, 397-444. [CrossRef]

75. Aalbers, M.B. The Great Moderation, the Great Excess and the global housing crisis. Int. J. Hous. Policy 2015, 15, 43-60. [CrossRef]

76. Vandecasteele, I.; Baranzelli, C.; Siragusa, A.; Aurambout, J.P.; Alberti, V.; Alonso Raposo, M.; Attardo, C.; Auteri, D.; Ribeiro Barranco, R.; Batista, E.; et al. The Future of Cities-Opportunities, Challenges and the Way Forward; Publications Office of the European Union: Luxembourg, 2019; ISBN 978-92-76-03848-1.

77. Lux, M. Efficiency and effectiveness of housing policies in the Central and Eastern Europe countries. Eur. J. Hous. Policy 2003, 3, 243-265. [CrossRef]

78. Matlack, J.L.; Vigdor, J.L. Do rising tides lift all prices? Income inequality and housing affordability. J. Hous. Econ. 2008, 17, 212-224. [CrossRef]

Publisher's Note: MDPI stays neutral with regard to jurisdictional claims in published maps and institutional affiliations.

(C) 2020 by the authors. Licensee MDPI, Basel, Switzerland. This article is an open access article distributed under the terms and conditions of the Creative Commons Attribution (CC BY) license (http://creativecommons.org/licenses/by/4.0/). 